\title{
1. Rock against the Trans-Pacific Partnership: copyright law, the creative industries and internet freedom
}

\section{INTRODUCTION}

The Trans-Pacific Partnership (TPP) sought to provide for longer and stronger copyright protection for transnational corporations across the Pacific Rim. ${ }^{1}$ The agreement builds upon intellectual property agreements, such as the TRIPS Agreement 1994 and the WIPO Internet Treaties $1996 .^{2}$ Moreover, the TPP draws inspiration from domestic United States copyright laws, such as the Digital Millennium Copyright Act 1998 (US) and the Sonny Bono Copyright Term Extension Act 1998 (US). ${ }^{3}$ Furthermore, the TPP builds upon TRIPS+ bilateral agreements, such as the Australia-United States Free Trade Agreement 2004 and the Singapore-United States Free Trade Agreement 2003. ${ }^{4}$ The agreement recycles many of the provisions found in the failed TRIPS++ Agreement, the Anti-Counterfeiting Trade Agreement 2011..$^{5}$ Accordingly, the TPP could be described as a TRIPS++ Agreement. Rather radically, in addition to an extensive intellectual property chapter, the TPP also includes an investor-state dispute settlement regime (ISDS) - like the North American Free Trade Agreement $1994 .{ }^{6}$

1 The Trans-Pacific Partnership 2015. For general commentary on the TPP, see Jane Kelsey (ed.), No Ordinary Deal: Unmasking the Trans-Pacific Partnership Free Trade Agreement, Wellington: Bridget Williams Books Inc., 2010; Tania Voon (ed.), Trade Liberalisation and International Co-operation: A Legal Analysis of the Trans-Pacific Partnership Agreement, Cheltenham (UK) and Northampton (MA): Edward Elgar Publishing, 2013; C.L. Lim, Deborah Elms and Patrick Low (ed.), The Trans-Pacific Partnership: A Quest for a Twenty-First Century Trade Agreement, Cambridge: Cambridge University Press, 2012; Jane Kelsey, Hidden Agendas: What We Need to Know about the Trans-Pacific Partnership Agreement (TPPA), Wellington: Bridget Williams Books Limited, 2013; and Scott Sinclair and Stuart Trew (ed.), The Trans-Pacific Partnership and Canada: A Citizen's Guide, Toronto: James Lorimer \& Company Ltd., 2016.

$2 \quad$ TRIPS Agreement 19941869 UNTS 299; 33 ILM 1197 (1994), WIPO Copyright Treaty 1996 S. Treaty Doc. No. 105-17 (1997); 36 ILM 65 (1997); and WIPO Performances and Phonograms Treaty 1996 S. Treaty Doc. No. 105-17, 36 ILM 76 (1997).

3 The Digital Millennium Copyright Act 1998 (US) Pub. L. 105-304 and the Sonny Bono Copyright Term Extension 1998 (US) Pub.L. 105-298.

4 Australia-United States Free Trade Agreement (AUSFTA), signed 18 May 2004 (entered into force 1 January 2005); and Singapore-United States Free Trade Agreement, signed 6 May 2003 (entered into force 1 January 2003).

5 Anti-Counterfeiting Trade Agreement 2011, [2011] ATNIF 22, not yet in force.

$6 \quad$ North American Free Trade Agreement 199332 ILM 289, 605 (1993). 
There has been worry that the intellectual property chapter of the TPP will 'contribute to, rather than help to control, the increasing fragmentation of international IP lawmaking'.

The TPP-11 has suspended a number of the more controversial copyright provisions relating to copyright term, intermediary liability, technological protection measures, rights management of information and the protection of encrypted program-carrying satellite and cable signals. ${ }^{8}$ However, there has been concern that such measures will be revived in the future - either by the members themselves, or through the return of the United States to the negotiations. The USMCA provides for an extensive intellectual property chapter, although it winds down the operation of ISDS. ${ }^{9}$ The USMCA is another example of a TRIPS++ agreement.

The TPP has seen a raging debate over copyright law, policy and practice. The controversy has not necessarily followed the patterns of past copyright controversies over the Stop Online Piracy Act and the Anti-Counterfeiting Trade Agreement 2011. ${ }^{10}$ It has been noticeable that the information technology bodies which protested against past copyright industry proposals have relented in their criticism in the debate over the TPP. It was striking that the Obama Administration was able to obtain support for the TPP from both copyright content industries in publishing, music and film, and members of the digital economy. Civil society groups, though, have banded together to resist the adoption and implementation of the trade agreement.

The United States Chamber of Commerce was a key architect of the TPP. The Chamber aggressively pushed for high standards in the intellectual property chapter of the TPP: 'Given that the TPP is intended to serve as a model for future Asia-Pacific-U.S. trade agreements, it is critical that the TPP Agreement incorporates robust intellectual property (IP) protections.' ${ }^{11}$ The Chamber maintains: 'Pursuing comprehensive and commercially meaningful IP obligations will not only benefit U.S. interests, but will also help bring investment, innovation, and jobs to all TPP economies. ${ }^{\prime 2}$ The Chamber has been hostile to the inclusion of intellectual property flexibilities in the TPP. ${ }^{13}$

The Motion Picture Association of America (MPAA) has boasted that the TPP will foster digital trade and grow the economy. Anissa Brennan, the Senior Vice President for International Affairs for the MPAA, was enthusiastic about the agreement. ${ }^{14}$ She maintained that the agreement 'will foster the growth of online distribution with its market opening disciplines and robust protections for copyright'. ${ }^{15}$ Brennan argued that 'the TPP harmonizes

7 Kimberlee Weatherall, 'The TPP as a Case Study of Changing Dynamics for International Intellectual Property Negotiations' in Tania Voon (ed.), Trade Liberalisation and International Co-operation: A Legal Analysis of the Trans-Pacific Partnership Agreement, Cheltenham (UK) and Northampton (MA): Edward Elgar Publishing, 2013, 50-74 at 74.

$8 \quad$ Comprehensive and Progressive Agreement for Trans-Pacific Partnership 2018.

$9 \quad$ United States-Mexico-Canada Agreement 2018.

10 Stop Online Piracy Act HR 3261; and Anti-Counterfeiting Trade Agreement 2011, [2011] ATNIF 22 , not yet in force.

11 United States Chamber of Commerce, 'Global Intellectual Property Center'.

12 Ibid.

13 Mark Elliot of the United States Chamber of Commerce, 'NAFTA at Twenty: Accomplishments, Challenges, and the Way Forward on Intellectual Property', United States House Committee on Foreign Affairs, Subcommittee on the Western Hemisphere, 15 January 2014.

14 Anissa Brennan, 'The TPP will Foster Digital Trade and Grow Our Economy', The Motion Picture Association of America, 18 February 2016.

15 Ibid. 
copyright protections, which will facilitate global trade in creative works, including online' ${ }^{16}$ However, the film industry itself has much more mixed interests in the field of copyright law. As Ted Johnson said: 'While Hollywood's interests often lie in protecting intellectual property, independent filmmakers and documentary producers depend heavily on U.S. copyright law's concept of "fair use," or the use of material without authorization of the owner." ${ }^{17}$

The Recording Industry Association of America (RIAA) was disappointed by the collapse of the Anti-Counterfeiting Trade Agreement. ${ }^{18}$ The music industry has sought to promote a similar copyright maximalist agenda in the TPP. Chairman and CEO of the RIAA, Cary Sherman, was delighted by the conclusion of the Pacific Rim trade agreement. He reflected: 'Music is increasingly a global phenomenon and the modern music business derives the vast majority of its revenues from an extensive array of digital platforms.' ${ }^{19}$ Neil Turkewitz of the RIAA maintained that the TPP was 'critical to sustaining America's creative sector', ${ }^{20}$ He insisted: 'While the TPP may not provide a precise roadmap for realizing the potential of Internet commerce, it certainly moves us in the right direction. ${ }^{21}$ There has been disquiet, though, as to whether the trade agreement will privilege the interests of the music industry above those of creative artists. ${ }^{22}$

The Computer and Communications Industry Association (CCIA) has supported the $T P P .^{23}$ Its members include a broad section of the information technology industry, including Amazon, eBay, Facebook, Google, Microsoft, Netflix, PayPal, Pinterest, Samsung, TiVo, and Yahoo! The Association spans a wide spectrum of positions in the copyright public policy debate. While computer software companies like Microsoft have been copyright maximalists, search engines and social media companies have worried about copyright exceptions and intermediary liability issues surrounding safe harbours. Executive Officer Ed Black has maintained that the TPP promotes a balanced approach to copyright law: 'As digital trade takes a rising role in U.S. exports and the Internet becomes an increasingly crucial tool for traditional businesses, trade agreement language such as balanced copyright provisions will be crucial - not just to the digital economy but the growth of our overall economy. ${ }^{24}$ This seems a contentious claim given that, in a number of respects, the intellectual property chapter is quite unbalanced and distorted towards the rights of copyright owners. The communications

\footnotetext{
16 Ibid.

17 Ted Johnson, 'How the Trans-Pacific Partnership Could Impact Hollywood', Variety, 5 October 2015.

18 Pedro Roffe and Xavier Seuber (ed.), The ACTA and The Plurilateral Enforcement Agenda: Genesis and Aftermath, Geneva: International Centre for Trade and Sustainable Development and Cambridge: Cambridge University Press, 2014.

19 Recording Industry Association of America, 'RIAA Comment on Conclusion of TPP Negotiations', Press Release, 5 October 2015.

20 Dan Rys, 'RIAA Calls Trans-Pacific Partnership "Critical to Sustaining America's Creative Sector", Billboard, 6 November 2015.

21 Ibid.

22 Parker Higgins and Sarah Jeong, 'The TPP's Attack on Artists' Termination Rights', Electronic Frontier Foundation, 16 December 2013.

23 Computer and Communications Industry Association, 'Trans-Pacific Partnership'.

${ }^{24}$ Heather Greenfield, 'CCIA Hails TPA Provisions on Digital Trade; Applauds Congressional Committees' Commitment to Balanced Copyright in Trade Promotion Reports', Computer and Communications Industry Association, 14 May 2015.
} 
companies seem to be willing to suffer the risks of the intellectual property chapter in return for the perceived benefits of the electronic commerce chapter of the TPP.

The Internet Association has expressed support for the TPP. ${ }^{25}$ While harbouring some reservations about the intellectual property measures in the agreement, the big information technology companies in the Internet Association were attracted by the electronic commerce chapter.

Even more surprisingly, the Consumer Electronics Association has lent its support to the TPP. ${ }^{26}$ Historically, the Consumer Electronics Association has been a champion of consumer rights in respect of copyright law. ${ }^{27}$ Indeed, the Consumer Electronics Association has argued for a broad reading of the Sony Betamax decision, calling the decision 'the Magna Carta of our Industry' ${ }^{28}$ The organisation has promoted time-shifting, space-shifting and place-shifting technologies. In this context, it was striking that Gary Shapiro, president and CEO of the Consumer Electronics Association, expressed his support for the deal: 'With continued expansion of the digital economy and global supply chain, international trade is a driving force of revenue for U.S. businesses large and small. ${ }^{29}$ He maintained: 'CEA has long supported trade deals that reflect balanced copyright principles and the realities of the 21 st Century, including the growing role of the Internet and digital economy.' ${ }^{30}$ Shapiro argued: 'By removing trade barriers and promoting innovation and sustainable growth across the Asia-Pacific region, the TPP stands to benefit American businesses and workers through increased exports, greater contributions to the U.S. economy and the creation of new, high-paying jobs. ${ }^{31}$ However, the content of the intellectual property chapter does seem to undercut and undermine the Consumer Electronics Association's long-standing efforts to promote consumer rights in copyright law.

While Big IT has supported the trade agreement, other smaller players have shown reservations about the deal. Digital rights activist Cory Doctorow has complained: 'There is only one reason to negotiate an Internet treaty in secret: because you want to break the Internet. ${ }^{32} \mathrm{On}$ 20 March 2014, 25 leading technology companies wrote to the United States Congress, asking its representatives to oppose any form of fast-track authority for trade agreements like the $T P P .^{33}$ The signatories included reddit, Automattic (the company behind WordPress), Imgur, DuckDuckGo, CREDO Mobile, BoingBoing, Thoughtworks, Namecheap and Cheezburger. The letter emphasises that massive trade deals like the TPP are an 'emerging front in the battle

25 Internet Association, 'Statement in Support of the Trans-Pacific Partnership', Press Release, 30 March 2016.

${ }_{26}$ Consumer Electronics Association, 'CEA Applauds U.S., 11 Other Nations for Trans-Pacific Partnership Deal', Press Release, 5 October 2015.

27 Matthew Rimmer, Digital Copyright and the Consumer Revolution: Hands off my iPod, Cheltenham (UK) and Northampton (MA): Edward Elgar, 2007.

28 Gary Shapiro, 'Testimony on Behalf of the Consumer Electronics Association and the Home Recording Rights Coalition in the United States Senate Committee on the Judiciary', 28 September 2005.

29 Consumer Electronics Association, 'CEA Applauds U.S., 11 Other Nations for Trans-Pacific Partnership Deal’, Press Release, 5 October 2015.

30 Ibid.

31 Ibid.

32 Common Dreams, 'New Campaign Launched: "10 Days to Stop Fast Track" Brings Together Diverse Network of Labor, Internet, and Environmental Activists', Common Dreams, 23 January 2014.

33 Parker Higgins and Maira Sutton, 'Tech Companies Urge Senator Wyden to Reject Fast Track and Bring Transparency to TPP’, Electronic Frontier Foundation, 20 March 2014. 
to defend the free Internet' ${ }^{34}$ The technology companies warn: 'These highly secretive, supranational agreements are reported to include provisions that vastly expand on any reasonable definition of "trade," including provisions that impact patents, copyright, and privacy in ways that constrain legitimate online activity and innovation. ${ }^{35}$ The technology companies were concerned that the trade deal, with its intellectual property chapter and its investment chapter, will frustrate domestic law reform: 'In light of these needed revisions, the U.S. system cannot be crystallized as the international norm and should not be imposed on other nations. ${ }^{36}$ The technology companies stressed: 'It is crucial that we maintain the flexibility to re-evaluate and reform our legal framework in response to new technological realities. ${ }^{37}$ They emphasised: 'Ceding national sovereignty over critical issues like copyright is not in the best interest of any of the potential signatories of this treaty.' 38

A coalition of civil society groups have been concerned about how the trade agreement will impact upon digital rights, freedom of speech, privacy and an open internet. WikiLeaks played a key role in revealing drafts of the secret negotiations in respect of intellectual property. With a release of an early draft of the intellectual property chapter in 2013, Julian Assange, the editor of WikiLeaks, warned:

If instituted, the TPP's IP regime would trample over individual rights and free expression, as well as ride roughshod over the intellectual and creative commons. If you read, write, publish, think, listen, dance, sing or invent; if you farm or consume food; if you're ill now or might one day be ill, the TPP has you in its crosshairs. ${ }^{39}$

Knowledge Ecology International (KEI) has been critical of how the secret negotiations in the TPP have compromised multilateral efforts on development, education and access to knowledge. ${ }^{40}$ The Creative Commons movement warned that the TPP would harm user rights and the commons. ${ }^{41}$ The Wikimedia Foundation - which represents Wikipedia - has been worried about the implications of the copyright term extension for a free and open culture. ${ }^{42}$ Open Media has been concerned that the TPP will result in censorship of the internet. ${ }^{43}$ Privacy organisations such as the Australian Privacy Foundation have protested about the privacy outcomes of the $T P P .{ }^{44} \mathrm{~A}$ study commissioned

\footnotetext{
34 Technology Companies, 'Letter to Senator Ron Wyden', 20 March 2014.

35 Ibid.

36 Ibid.

37 Ibid.

38 Ibid.

39 WikiLeaks, 'Secret Trans-Pacific Partnership Agreement (TPP) - IP Chapter', Press Release, 13 November 2013.

40 James Love, 'Knowledge Ecology International Analysis of TPP IPR Text, from August 30, 2013', Knowledge Ecology International, 13 November 2013.

41 Creative Commons, 'The Trans-Pacific Partnership Would Harm User Rights and the Commons', 16 November 2015.

42 Wikimedia, 'What's the TPP? The Problematic Partnership', Medium, 3 February 2016.

43 Open Media, 'The TPP Was Just Signed - Now the Final Battle Begins'.

44 Australian Privacy Foundation, 'Re: Trans-Pacific Partnership Agreement', Joint Standing Committee on Treaties, 10 March 2016.
} 
by the Law Foundation New Zealand and Internet NZ has raised questions about the impact of the intellectual property regime in the TPP upon information technology. ${ }^{45}$

A number of creative artists - including Tom Morello, Talib Kweli, Evangeline Lilly, Anti-Glag, Jolie Holland, the Downtown Boys and Sihasin - have participated in a series of concerts named 'Rock against the TPP' to raise awareness and opposition to the TPP. ${ }^{46}$ The event was organised by Tom Morello's label Firebrand Records and the digital rights group Fight for the Future. ${ }^{47}$ The press release for the tour said: 'The TPP has little to do with trade, but would provide multinational corporations with new rights and powers that threaten good paying jobs, Internet freedom, the environment, access to medicine, and food safety. ${ }^{48}$

There have also been concerns about how the regional trade agreement will affect developing countries, such as Vietnam, which have pressing imperatives for education, access to knowledge and development. ${ }^{49}$ The TPP undercuts and undermines the WIPO Development Agenda. ${ }^{50}$

Drawing upon research into intellectual property and trade, this chapter of the book provides a critical evaluation of the copyright regime proposed by the TPP. In particular, this study focuses upon key participants in the trade negotiations: the United States; Canada; Australia; and New Zealand. The argument is that such a regime will have a negative impact upon creativity, innovation and competition in the Pacific Rim. Section 1 considers the negotiations in the TPP over the objectives of copyright law, the duration of copyright protection and the public domain. Section 2 focuses upon the successive copyright term extensions in the United States, and their impact upon creativity, cultural heritage, economics, competition and public welfare. It also looks at the ongoing debate over orphan works. Section 3 examines Canada's resistance to pressure for copyright term extensions in the TPP. It also notes Canada's capitulation to the demands for a copyright term extension in the USMCA. Section 4 looks at Australia's copyright term extension as part of the Australia-United States Free Trade Agreement 2004. Section 5 explores the costs of a copyright term extension in New Zealand. Section 6 focuses upon the situation in Japan, where a copyright term extension is taking place, despite the suspension in the TPP-11 on copyright term extension. Section 7 examines the outlier of Mexico, with its extremely long copyright duration. It also considers how other jurisdictions in the Pacific Rim would be affected by a copyright term extension.

45 James Ting-Edwards, Melanie Johnson, Judge David Harvey, Debbie Monahan, Kate McHaffie, and Jo Shaw, 'TPPA: Intellectual Property and Information Technology', The Law Foundation New Zealand and Internet NZ, February 2016.

46 Rock Against the TPP, www.rockagainsthetpp.org/

47 Fight for the Future, 'Rock Against the TPP: Tom Morello and Actress Evangeline Lilly to Headline Kick-off Event for Nationwide Concert Tour Opposing the Trans-Pacific Partnership', 15 June 2016; William Maudlin, 'Anti-TPP Concerts Put a Spotlight on a Hollywood Trade Divide', The Wall Street Journal, 20 July 2016 and Mazin Sidahmed, 'Tom Morello and Talib Kweli Protest against TPP as Fellow Stars Stay Quiet', The Guardian, 2 August 2016.

48 Ibid.

49 Krista Cox, 'The Intellectual Property Chapter of the Trans-Pacific Partnership Agreement and Investment in Developing Nations' (2014) 35 (4) University of Pennsylvania Journal of International Law 1045-59.

50 WIPO Development Agenda. 


\section{The TPP Negotiations}

\section{A. Objectives of copyright law}

There has long been a philosophical debate over the aims, objectives, and purposes of copyright law. ${ }^{51}$

The TRIPS Agreement 1994 highlights the regulatory autonomy of nations in fashioning intellectual property regimes which are appropriate and adapted for their development. ${ }^{52}$

Superior courts across the Pacific Rim have emphasised that copyright law is designed to serve higher public purposes. The legal regime is not merely an instrument of private profit.

It has been striking that such values articulated by superior courts have not been evident in the drafts or in the final text of the TPP. The intellectual property chapter of the TPP seeks to provide for longer and stronger copyright protection for transnational corporations. It is underpinned by a corporatist vision of copyright law. The key objective seems to be to protect the investment of multinational copyright aggregators in the fields of music, film and publishing. The proposed regime does not seem particularly advantageous for creative artists (particularly in light of the lack of comprehensive moral rights protection). Likewise, there is little in the intellectual property chapter of the TPP which boosts the public domain and the intellectual commons. The TPP engages in a radical discourse shift about copyright law - emphasising that it is a vehicle for foreign investment and regional trade in the Asia-Pacific.

WikiLeaks published a draft intellectual property chapter of the TPP in November $2013 .{ }^{53}$

What was missing, as the Electronic Frontier Foundation observed, was any recognition of the public interests to be served by copyright law:

The leaked text, from August 2013, confirms long-standing suspicions about the harm the agreement could do to users' rights and a free and open Internet. From locking in excessive copyright term limits to further entrenching failed policies that give legal teeth to Digital Rights Management (DRM) tools, the TPP text we've seen today reflects a terrible but unsurprising truth: an agreement negotiated in near-total secrecy, including corporations but excluding the public, comes out as an anti-user wish list of industry-friendly policies. ${ }^{54}$

Instead of promoting the progress of science and the useful arts, the TPP transforms intellectual property into a means to protect and secure the investment of transnational corporations.

Professor Michael Geist of the University of Ottawa said that there was a debate over the philosophical goals of intellectual property:

[Other nations have argued for] balance, promotion of the public domain, protection of public health, and measures to ensure that IP rights themselves do not become barriers to trade. The opposition to

51 Peter Drahos, A Philosophy of Intellectual Property, Aldershot: Ashgate, 1996.

52 Alison Slade, "The "Objectives" and "Principles" of the WTO TRIPS Agreement: A Detailed Anatomy’ (2016) 53 (3) Osgoode Hall Law Journal 948-98.

53 WikiLeaks, 'Advanced Intellectual Property Chapter for All 12 Nations with Negotiating Positions (30 August 2013 consolidated bracketed negotiating text)'.

54 Parker Higgins and Maira Sutton, 'TPP Leak Confirms the Worst: US Negotiators Still Trying to Trade Away Internet Freedoms', Electronic Frontier Foundation, 13 November 2013. 
these objective[s] by the US and Japan (Australia has not taken a position) speaks volumes about their goals for the TPP. ${ }^{55}$

It is particularly disappointing that other participating nations in the TPP have been partners to the United States in the Pacific Rim negotiations, showing little inclination to stand up for the public interest in debates over copyright law.

Article 18.2 of the TPP discusses the objectives of the agreement in respect of intellectual property:

The protection and enforcement of intellectual property rights should contribute to the promotion of technological innovation and to the transfer and dissemination of technology, to the mutual advantage of producers and users of technological knowledge and in a manner conducive to social and economic welfare, and to a balance of rights and obligations. ${ }^{56}$

This language echoes the language on Objectives in Article 7 of the TRIPS Agreement 1994.

Article 18.3 (1) of the TPP considers the relationship between intellectual property and development: 'A Party may, in formulating or amending its laws and regulations, adopt measures necessary to protect public health and nutrition, and to promote the public interest in sectors of vital importance to their socio-economic and technological development, provided that such measures are consistent with the provisions of this Chapter. ${ }^{57}$ Article 18.3 (2) of the TPP considers intellectual property and competition policy: 'Appropriate measures, provided that they are consistent with the provisions of this Chapter, may be needed to prevent the abuse of intellectual property rights by right holders or the resort to practices which unreasonably restrain trade or adversely affect the international transfer of technology'. ${ }^{58}$ Such measures mirror Article 8 of the TRIPS Agreement 1994.

Article 18.4 of the TPP is a novelty, discussing 'Understandings in Respect of this Chapter' ${ }^{59}$ This long-winded provision stipulates:

Having regard to the underlying public policy objectives of national systems, the Parties recognise the need to: (a) promote innovation and creativity; (b) facilitate the diffusion of information, knowledge, technology, culture and the arts; and (c) foster competition and open and efficient markets, through their respective intellectual property systems, while respecting the principles of transparency and due process, and taking into account the interests of relevant stakeholders, including right holders, service providers, users and the public. ${ }^{60}$

In earlier drafts of this provision, there had been mention of the importance of the public domain. However, the United States and Japan blocked mention of the public domain in this particular article of the agreement.

\footnotetext{
55 Michael Geist, 'The Trans-Pacific Partnership IP Chapter Leaks: Canada Pushing Back against Draconian U.S. Demands', the University of Ottawa, 13 November 2013.

Article 18.2 of the Trans-Pacific Partnership 2015.

Article 18.3 (1) of the Trans-Pacific Partnership 2015.

Article 18.3 (2) of the Trans-Pacific Partnership 2015.

Article 18.4 of the Trans-Pacific Partnership 2015.

60 Article 18.4 of the Trans-Pacific Partnership 2015.
} 
Instead, in the final text, there is a displaced discussion of the public domain in Article 18.15 of the TPP. ${ }^{61}$ Article 18.15 (1) provides that 'the Parties recognise the importance of a rich and accessible public domain'. ${ }^{62}$ Article 18.15 (2) observes that 'the Parties also acknowledge the importance of informational materials, such as publicly accessible databases of registered intellectual property rights that assist in the identification of subject matter that has fallen into the public domain. ${ }^{63}$ For all their rhetorical force, the provisions on the public domain seem rather hollow and empty. There does not seem to be any obligations placed upon nation states in the Pacific Rim in preserving, conserving or expanding 'a rich and accessible public domain'.

The Creative Commons movement has been particularly concerned about the treatment of the public interest in access to knowledge. ${ }^{64}$ Discussing Article 18.15, the Creative Commons observed that the mention of the public domain is 'lip service' at best:

The inclusion of this text might otherwise have been viewed as a welcome addition, but taken in context of the rest of the document - for example in the extension of copyright terms - it does not seem that the negotiating parties care much about promoting access to and expansion of the public domain. ${ }^{65}$

The Creative Commons movement observed: 'In prior leaked drafts of the IP chapter the substance and placement of mentions of the public domain were more prominent and supportive of the public interest. ${ }^{96}$ The Creative Commons highlighted the excision of such terminology: 'These are no longer reflected in the text. ${ }^{67}$

It is also notable that the TPP shows little interest in the WIPO Development Agenda, with its goals of promoting the millennium development goals through intellectual property law, policy and practice. ${ }^{68}$ The new 2015 United Nations Sustainable Development Goals include a focus upon quality education. ${ }^{69}$ Arguably, there is a lack of engagement by the TPP with the role played by copyright law in respect of literacy, education and knowledge. Farida Shaheed, UN special rapporteur on cultural rights, has raised questions about the relationship between copyright law, trade, cultural identity and scientific progress. ${ }^{70}$ She calls for

a human rights based approach to copyright issues, which would help focus attention on important themes that may be lost when copyright is treated primarily in terms of trade: the social function and human dimension of intellectual property, the public interests at stake, the importance of transparency and public participation in policymaking, the need to design copyright rules to genuinely benefit human authors, the importance of broad diffusion and cultural freedom, not-for-profit cultural

Article 18.15 of the Trans-Pacific Partnership 2015.

Article 18.15 (1) of the Trans-Pacific Partnership 2015.

Article 18.15 (2) of the Trans-Pacific Partnership 2015.

64 Creative Commons, 'The Trans-Pacific Partnership Would Harm User Rights and the Commons', 16 November 2015.

65 Ibid.

66 Ibid.

67 Ibid.

68 WIPO Development Agenda.

69 United Nations Sustainable Development Goals.

70 Farida Shaheed, 'Statement made by the Special Rapporteur on Cultural Rights at the 28th session of the Human Rights Council', 11 March 2015. 
production and innovation, and the special consideration for the impact of copyright law upon marginalised or vulnerable groups. ${ }^{71}$

Such multilateral work highlights larger questions about the relationship between intellectual property and human rights.

The TPP privileges corporate values in respect of its aims, objectives and purposes for copyright law. More traditional objectives in respect of copyright law - such as promoting learning, access to knowledge and education - have been sublimated and suppressed. The $T P P$ distorts the aims, objectives and principles of copyright law. The agreement privileges a corporatist view of copyright law, and seeks to enhance the rights and remedies of copyright owners. The trade agreement is unbalanced. There is a failure to properly represent the traditional objectives of copyright law in promoting learning, access to knowledge and scientific progress. Moreover, the TPP does not promote copyright goals, such as creativity, innovation, competition and access to goods and services.

\section{B. Copyright term extension in the TPP}

The TPP has sought to extend the term of copyright across the Pacific Rim. The extended copyright term could impoverish the number and variety of works in the public domain. Given the uneven distribution of copyright terms across the Asia-Pacific, the copyright term extension would be entrenched in countries such as the United States and Australia. For Canada and New Zealand, there would need to be a further lengthening of the copyright term.

The WikiLeaks texts revealed the variations in the negotiating positions of the member states. $^{72}$ In the negotiations, the United States, Australia, Peru, Singapore and Chile proposed a term of life plus 70 years for natural persons. Mexico wanted copyright protection for life plus 100 years. ${ }^{73}$ New Zealand, Canada and other countries who followed the Berne Convention norm particularly stand to suffer, given they only have a copyright term of life plus 50 years. For corporate-owned works, the United States has proposed 95 years of protection, while Australia, Peru, Singapore and Chile are pushing for 70. The United States Trade Representative's proposals in respect of copyright term extension in the TPP would be a form of corporate welfare. Such windfalls would be unjustified and undeserved. A copyright term extension throughout the Pacific Rim would have an adverse impact upon cultural heritage, innovation, competition and freedom of speech.

\footnotetext{
71 Ibid.

72 WikiLeaks, 'Advanced Intellectual Property Chapter for All 12 Nations with Negotiating Positions (30 August 2013 consolidated bracketed negotiating text)'.

73 Blayne Haggart, Copyfight: The Global Politics of Digital Copyright Reform, Toronto: University of Toronto Press, 2014.
} 
Article 18.63 of the TPP deals with the term of protection for copyright and related rights:

Each Party shall provide that in cases in which the term of protection of a work, performance or phonogram is to be calculated:

(a) on the basis of the life of a natural person, the term shall be not less than the life of the author and 70 years after the author's death; and

(b) on a basis other than the life of a natural person, the term shall be:

(i) not less than 70 years from the end of the calendar year of the first authorised publication of the work, performance or phonogram; or

(ii) failing such authorised publication within 25 years from the creation of the work, performance or phonogram, not less than 70 years from the end of the calendar year of the creation of the work, performance or phonogram. ${ }^{74}$

Footnote 73 provides:

For greater certainty, in implementing this Article, nothing prevents a Party from promoting certainty for the legitimate use and exploitation of a work, performance or phonogram during its term of protection, consistent with Article 18.65 (Limitations and Exceptions) and that Party's international obligations. $^{75}$

Footnote 74 stipulates:

The Parties understand that if a Party provides its nationals a term of copyright protection that exceeds life of the author plus 70 years, nothing in this Article or Article 18.8 (National Treatment) shall preclude that Party from applying Article 7.8 of the Berne Convention with respect to the term in excess of the term provided in this subparagraph of protection for works of another Party. ${ }^{76}$

Footnote 75 explains:

For greater certainty, for the purposes of subparagraph (b), if a Party's law provides for the calculation of term from fixation rather than from the first authorised publication, that Party may continue to calculate the term from fixation. ${ }^{77}$

\section{Footnote 76 stresses:}

For greater certainty, a Party may calculate a term of protection for an anonymous or pseudonymous work or a work of joint authorship in accordance with Article 7(3) or Article 7bis of the Berne Convention, provided that the Party implements the corresponding numerical term of protection required under this Article. ${ }^{78}$

In the end, the final text of the agreement contains a number of provisions in respect of the copyright term and the TPP.

Hollywood has been a prime mover behind the push for a copyright term extension. Anissa Brennan, Senior Vice President of the Motion Picture Association of America, explained the

Article 18.63 of the Trans-Pacific Partnership 2015.

Article 18.63 of the Trans-Pacific Partnership 2015.

Article 18.63 of the Trans-Pacific Partnership 2015.

Article 18.63 of the Trans-Pacific Partnership 2015.

78 Article 18.63 of the Trans-Pacific Partnership 2015. 
film industry's objectives in the TPP. ${ }^{79}$ She emphasised that 'the TPP harmonizes the term of protection for copyrighted works to the global minimum standard' ${ }^{80}$ Brennan maintained: 'The TPP is a significant accomplishment with equally significant potential to foster legitimate global trade in creative works by opening foreign markets and protecting creative rights. ${ }^{91}$ She insisted that 'this will strengthen U.S. competitiveness and allow creativity and innovation to continue to thrive in the digital age'. ${ }^{82}$

Disney is famous for lobbying for a copyright term extension both in the United States and elsewhere throughout the Pacific Rim. The heavy-handed involvement of Disney in the trade negotiations was revealed by its own leader in a candid letter to his employees. Disney Chief Executive Officer Bob Iger boasted to his employees about his company's success in including a range of intellectual property measures in the $T P P .{ }^{83} \mathrm{He}$ asked his employees to contribute to the company's political action committee, DisneyPAC. The 2015 letter stressed that Disney had been influential in trade negotiations in the United States, noting that the ' $T P P$ will establish a strong baseline of protection for intellectual property while breaking down trade barriers in the Asia Pacific region' ${ }^{84}$ Iger observed that 'in the coming year, we expect Congress and the Administration to be active on copyright regime issues, efforts to enact legislation to approve and implement the TPP trade agreement, tax reform, and more proposals to weaken retransmission consent, to name a few. ${ }^{95}$ He hoped that Disney would build upon its trade achievements in other areas:

2016 should see significant activity in negotiations between the US and China over a Bilateral Investment Treaty (BIT), continued negotiations with the European Union over the proposed Transatlantic Trade and Investment Partnership agreement, the 50-country Trade in Services Agreement negotiations, and efforts by the US Government to raise IP standards and break down trade barriers through a variety of means. ${ }^{86}$

This letter reveals how Disney is seeking to use a combination of trade agreements to secure its objectives in respect of intellectual property rights and enforcement.

\section{TPP-11 and USMCA}

With the departure of the United States, the copyright term extension was suspended in the TPP-11. ${ }^{87}$ Michael Geist praised the decision of Canada to push for a suspension of the copyright term extension in this agreement: 'The TPP-11 outcome also confirms - yet again - that there is simply no need for excessively restrictive IP rules in modern trade agreements. ${ }^{98} \mathrm{He}$

\footnotetext{
79 Anissa Brennan, 'The TPP will foster Digital Trade and Grow Our Economy', Motion Picture Association of America, 18 February 2016.

80 Ibid.

81 Ibid.

82 Ibid.

83 Joe Mullin, 'Disney CEO Asks Employees to Chip In to Pay Copyright Lobbyists', ArsTechnica, 26 February 2016.

84 Ibid.

85 Ibid.

86 Ibid.

87 Comprehensive and Progressive Agreement for Trans-Pacific Partnership 2018.

88 Michael Geist, 'Bursting the IP Trade Bubble: Canada's Position on IP Rules Takes Shape with Suspended TPP Provisions', University of Ottawa, 16 November 2017.
} 
noted: 'The TPP-11, the Canada-South Korean trade agreement, and CETA all feature robust IP chapters but do not include provisions such as mandatory copyright term extension beyond international treaty requirements. ${ }^{99}$ Geist cautioned: 'The NAFTA negotiations, however, will represent a much more difficult challenge as the U.S. is likely to re-assert $T P P$-style demands in that agreement. ${ }^{90}$ His warning about the NAFTA negotiations proved to be quite prescient and prophetic.

Much as Professor Michael Geist feared, the USMCA contains a copyright term extension. ${ }^{91}$ Article 20.63 addresses the term of protection for copyright and related rights, providing:

Each Party shall provide that in cases in which the term of protection of a work, performance, or phonogram is to be calculated:

(a) on the basis of the life of a natural person, the term shall be not less than the life of the author and 70 years after the author's death; and

(b) on a basis other than the life of a natural person, the term shall be:

(i) not less than 75 years from the end of the calendar year of the first authorized publication of the work, performance, or phonogram, or

(ii) failing such authorized publication within 25 years from the creation of the work, performance, or phonogram, not less than 70 years from the end of the calendar year of the creation of the work, performance, or phonogram. ${ }^{92}$

When that regime comes into force, the United States, Mexico and Canada will have to meet its minimum standards in respect of the copyright term extension. In practice, this means that Canada will have to engage in a copyright term extension. So after resisting a copyright term extension in the TPP-11, Canada has in the end belatedly capitulated to a copyright term extension as part of the USMCA.

University of Illinois Professor Paul Heald has contended that such a copyright term extension would be a tax on consumers in Canada. ${ }^{93} \mathrm{He}$ has conducted a number of empirical studies into the impact of the copyright term upon the public domain. ${ }^{94}$

\section{United States of America}

The Supreme Court of the United States has discussed the nature, role and function of copyright law in a range of precedents. There has been a great deal of philosophical debate between the judges on the bench as to the higher purposes served by copyright law.

\footnotetext{
89 Ibid.

90 Ibid.

91 United States-Mexico-Canada Agreement 2018 (USMCA) Signed 30 November 2018.

92 Article 20.63 of the United States-Mexico-Canada Agreement 2018 (USMCA) Signed 30 November 2018.

93 Michael Geist, 'Copyright Term Extension Is a Tax on Consumers - Paul Heald on What Extending Copyright Term Could Mean for Canada', The LawBytes Podcast, 24 February 2020.

94 Paul Heald, 'How Copyright Keeps Works Disappeared' (2014) 11 (4) Journal of Empirical Legal Studies 829-66; Paul Heald, Kris Erickson and Martin Kretschmer, 'The Valuation of Unprotected Works: A Case Study of Public Domain Images on Wikipedia' (2015) 29 Harvard Journal of Law and Technology 1-31; and Christopher Buccafusco and Paul Heald, 'Do Bad Things Happen When Works Enter the Public Domain? Empirical Tests of Copyright Term Extension' (2013) 28 Berkeley Technology Law Journal 1-44.
} 
In Harper \& Row v. Nation Enterprises, O'Connor J of the Supreme Court of the United States observed: 'The rights conferred by copyright are designed to assure contributors to the store of knowledge a fair return for their labors. ${ }^{95}$

In Feist Publications Inc. v. Rural Telephone Service Company, Inc., O'Connor J of the Supreme Court of the United States emphasised the higher purposes served by copyright law in the United States constitutional system:

The primary objective of copyright is not to reward the labor of authors, but 'to promote the Progress of Science and useful Arts.' Art. I, § 8, cl. 8. To this end, copyright assures authors the right to their original expression, but encourages others to build freely upon the ideas and information conveyed by a work. ${ }^{96}$

The decision highlights the constitutional objective of copyright law in preserving a public domain, and promoting the useful arts and the progress of science.

In Campbell v. Acuff-Rose Music Inc., Souter J of the Supreme Court of the United States stressed: 'From the infancy of copyright protection, some opportunity for fair use of copyrighted materials has been thought necessary to fulfill copyright's very purpose, "[t]o promote the Progress of Science and useful Arts". ${ }^{97}$ There has also been much debate about the competing objectives of copyright law in disputes over copyright term, ${ }^{98}$ peer-to-peer networks,${ }^{99}$ internet television, ${ }^{100}$ and trade. ${ }^{101}$ The Supreme Court of the United States, though, has sometimes been rather unpredictable in terms of its jurisprudence.

In response to the European Union harmonisation of copyright duration, the United States Congress passed the Sonny Bono Copyright Term Extension Act 1998 (US).

The copyright term extension in the United States was highly controversial, and the subject of a number of constitutional challenges. ${ }^{102}$ In the 2003 case of Eldred v. Ashcroft, the Supreme Court of the United States by a majority of seven to two upheld the constitutionality of the Sonny Bono Copyright Term Extension Act 1998 (US) ${ }^{103}$ For the majority, Ginsburg J held: 'As we read the Framers' instruction, the Copyright Clause empowers Congress to determine the intellectual property regimes that, overall, in that body's judgment, will serve the ends of the Clause. ${ }^{104}$ Breyer J dissented: 'The economic effect of this 20 -year extension - the longest blanket extension since the Nation's founding - is to make the copyright term not limited, but virtually perpetual.' ${ }^{105}$ Stevens J dissented that 'the requirement that those exclusive grants be for "limited Times" serves the ultimate purpose of promoting the "Progress of Science and

\footnotetext{
95 Harper \& Row v. Nation Enterprises 471 U.S. 539 (1985).

96 Feist Publications Inc. v. Rural Telephone Service Company, Inc. 499 U.S. 340 (1991).

97 Campbell v. Acuff-Rose Music, Inc. 510 U.S. 569 (1994).

$98 \quad$ Eldred v. Ashcroft 537 U.S. 186 (2003); and Golan v. Holder 609 F. 3d 1076 (2012).

99 MGM Studios, Inc. v. Grokster, Ltd. 545 U.S. 913 (2005)

100 American Broadcasting Cos. v. Aereo 134 S. Ct. 2498 (2014).

101 Kirtsaeng v. John Wiley \& Sons Inc. 133 S. Ct 1351 (2013).

102 Steven Seidenberg, 'US Perspectives: TPP's Copyright Term Benefits US, Burdens Others', Intellectual Property Watch, 23 March 2015.

103 Eldred v. Ashcroft 537 U.S. 186 (2003).

104 Eldred v. Ashcroft 537 U.S. 186 (2003).

105 Eldred v. Ashcroft 537 U.S. 186 (2003).
} 
useful Arts" by guaranteeing that those innovations will enter the public domain as soon as the period of exclusivity expires'. ${ }^{106}$

Professor Joseph Stiglitz has been highly critical of the copyright term extension in the United States. ${ }^{107} \mathrm{He}$ has observed:

There is no evidence of any innovative benefit of the extension to seventy years beyond the death of the author. This provision in the Copyright Term Extension Act was called the 'Mickey Mouse' provision - it was supported heavily by Disney, which controlled the copyright to Mickey Mouse - but beyond that, there was no societal benefit, and considerable cost in terms of the free flow of knowledge. ${ }^{108}$

Stiglitz is of the view that a copyright term extension serves to stifle innovation and access to knowledge in the United States. His collaborator Dean Baker has also investigated the economics of copyright term extensions, and has formed the conclusion that the costs far outweigh any benefits. ${ }^{109}$

In 2012, in the case of Golan v. Holder, the Supreme Court of the United States rejected a challenge to the restoration of copyright in foreign works. ${ }^{110}$ For the majority, Ginsburg $\mathrm{J}$ concluded 'that $\$ 514$ does not transgress constitutional limitations on Congress' authority'. ${ }^{111}$ Her Honour found: 'Neither the Copyright and Patent Clause nor the First Amendment, we hold, makes the public domain, in any and all cases, a territory that works may never exit.' 112 Breyer $\mathrm{J}$ - with whom Alito $\mathrm{J}$ joined - dissented that the statute 'bestows monetary rewards only on owners of old works - works that have already been created and already are in the American public domain'. ${ }^{113}$ Breyer J concluded:

The fact that, by withdrawing material from the public domain, the statute inhibits an important pre-existing flow of information is sufficient, when combined with the other features of the statute that I have discussed, to convince me that the Copyright Clause, interpreted in the light of the First Amendment, does not authorize Congress to enact this statute. ${ }^{114}$

Brewster Kahle of the Internet Archive brought a constitutional challenge in respect of copyright term extension, the removal of copyright registration and the problem of orphan works. ${ }^{115}$ The United States Court of Appeals for the Ninth Circuit rejected the challenge, finding that the matter had been previously dealt with in the case of Eldred v. Ashcroft. ${ }^{116}$ Farris $\mathrm{J}$ said: 'Despite Plaintiffs' attempt to frame the issue in terms of the change from an opt-in to an

\footnotetext{
106 Eldred v. Ashcroft 537 U.S. 186 (2003).

107 Joseph Stiglitz, People, Power, and Profits: Progressive Capitalism for an Age of Discontent, New York and London: W.W Norton \& Company, 2019, 74.

108 Ibid., 74.

109 Dean Baker, Rigged: How Globalization and the Rules of the Modern Economy Were Structured to Make the Rich Richer, Washington DC: Center for Economic and Policy Research, 2016, 91-5.

110 Golan v. Holder 609 F. 3d 1076 (2012).

111 Golan v. Holder 609 F. 3 d 1076 (2012).

112 Golan v. Holder 609 F. 3d 1076 (2012).

113 Golan v. Holder 609 F. 3d 1076 (2012).

114 Golan v. Holder 609 F. 3d 1076 (2012).

115 Kahle v. Gonzales 487 F. 3d 697 (9th Cir. 2007).

116 Eldred v. Ashcroft 537 U.S. 186 (2003).
} 
opt-out system rather than in terms of extension, they make essentially the same argument, in different form, that the Supreme Court rejected in Eldred. ${ }^{117}$

Although the United States Copyright Office has raised the problem of orphan works, ${ }^{118}$ the United States Congress has failed to legislate for effective remedies in respect of the problem. ${ }^{119}$ The CLASSICS Act has been of concern in terms of its impact on the copyright term of sound recordings. ${ }^{120}$

In the United States, there have been legal battles over copyright term and the public domain in respect of famous works such as the 'Happy Birthday' song. ${ }^{121}$ In this matter, there was a class action seeking to have a purported copyright covering the lyrics to 'Happy Birthday' declared invalid. ${ }^{122}$ In the end, there was a settlement, which recognised that the work was in the public domain. ${ }^{123}$ Jenn Nelson has explained her campaign to liberate the 'Happy Birthday' song and ensure that it joined the public domain. ${ }^{124}$

There has been a concerted new effort to challenge the copyright asserted in respect of other classic American musical works, such as 'We Shall Overcome' and 'This Land is Your Land. ${ }^{125}$

The lawyers challenging the copyright of 'We Shall Overcome' claimed that the work was an adaptation of an African American spiritual and was therefore in the public domain. The lawyers maintained that it was only subsequently adopted by folk singer Pete Seeger and copyrighted. Notably, in 1994, Pete Seeger asked for his name to be removed from the copyright. ${ }^{126}$ In 2017 , a court ruled in favour of the challengers to the copyright in respect of 'We Shall Overcome'. ${ }^{127}$ Cote J held that the versions of 'We Shall Overcome' in copyright applications

117 Eldred v. Ashcroft 537 U.S. 186 (2003).

118 United States Copyright Office, Orphan Works and Mass Digitization: A Report of the Register of Copyrights, Washington DC: United States Copyright Office, June 2015.

119 The Shawn Bentley Orphan Works Act of 2008 (US) proposed a limitation on remedies in respect of orphan works. However, the United States Congress failed to pass the measure.

120 The CLASSICS Act or Compensating Legacy Artists for their Songs, Service, and Important Contributions to Society Act 2017 (US) (H.R.3301) was consolidated into a larger bill, and passed as the Orrin G. Hatch Music Modernization Act 2018 (US). For criticism of the regime, see Equal Citizens, 'Fix the Classics Act', and Lawrence Lessig, 'Congress' Latest Move to Extend Copyright Protection is Misguided', Wired, 18 May 2018.

${ }_{121}$ Marya v. Warner/Chappell Music. Inc. 131 F. Supp. 3d 975 (2015).

122 Marya v. Warner/Chappell Music. Inc. 131 F. Supp. 3d 975 (2015).

123 Jess Denham, "'Happy Birthday" Song Now in the Public Domain after Judge Approves Settlement', Independent, 28 June 2016.

124 Jenn Nelson, 'Happy Birthday: My Campaign to Liberate the People's Song', The Guardian, 1 July 2016.

${ }_{125}$ Ben Sisariom, “A Fight to Make "We Shall Overcome" and "This Land is Your Land" Copyright Free', The New York Times, 12 July 2016.

126 Joe Mullin, 'Judge Throws Out 57-Year-Old Copyright on "We Shall Overcome", ArsTechnica, 12 September 2017.

127 We Shall Overcome Foundation and Butler Films LLC v. The Richmond Organization, Inc. (2017) $16 \mathrm{cv} 2725$. 
dated 1960 and 1963 were not 'sufficiently original to qualify as a derivative work'. ${ }^{128}$ In 2018 , the work 'We Shall Overcome' was put in the public domain in a copyright settlement. ${ }^{129}$

In contrast, the action over 'This Land is Your Land' has been unsuccessful as of 2020. ${ }^{130}$ The plaintiffs argued that Ludlow Music do not own valid copyright in 'This Land is Your Land'. ${ }^{131}$ They contended that Guthrie published the work in a 1945 songbook, which was never registered with the United States Copyright Office. They contended that any copyright that existed expired in 1973. The defendants argued that the matter should be dismissed because there was no longer a live case or controversy. The defendants relied on a broadly worded covenant not to sue the plaintiffs, and the refund of a compulsory licensing fee. Castel J held: 'Having reviewed the covenant not to sue, the Court concludes that it is extremely broad, covers past, present and future conduct by plaintiffs, their predecessors, successors, assigns and a host of others. ${ }^{132}$ The judge concluded that the 'Defendants have met their burden of showing that they could not reasonably be expected to resume their efforts to enforce against plaintiffs any right they may have under the copyright laws relating to the Song'. ${ }^{133}$ Accordingly, the judge granted the motion to dismiss the matter, in the absence of a live case or controversy.

There have also been significant conflicts over copyright law and the Sherlock Holmes canon. ${ }^{134}$ In his appeal judgment, Posner J expressed concerns about the 'quixotic' efforts of the Conan Doyle Estate to extend the term of copyright protection:

The spectre of perpetual, or at least nearly perpetual, copyright (perpetual copyright would violate the copyright clause of the Constitution, Art. I, $\S 8, \mathrm{cl} .8$, which authorizes copyright protection only for 'limited Times') looms, once one realizes that the Doyle estate is seeking 135 years (1887-2022) of copyright protection for the character of Sherlock Holmes as depicted in the first Sherlock Holmes story. ${ }^{135}$

His Honour highlighted the importance of the public domain in his judgment: 'Once the copyright on a work expires, the work becomes a part of the public domain and can be copied and sold without need to obtain a license from the holder of the expired copyright. ${ }^{, 136}$ Despite

128 We Shall Overcome Foundation and Butler Films LLC v. The Richmond Organization, Inc. (2017) $16 \mathrm{cv} 2725$.

129 Christopher Mele, "We Shall Overcome" Put in Public Domain in a Copyright Settlement', The New York Times, 26 January 2018; Michael Martin, "We Shall Overcome" Ruled Public Domain in Copyright Settlement', NPR, 27 January 2018, and Eriq Gardner, 'Song Publisher Agrees "We Shall Overcome" Is in Public Domain in Legal Settlement', The Hollywood Reporter, 26 January 2018.

130 Ben Sisario, "This Land Is Your Land" Is Still Private Property, Court Rules', The New York Times, 28 February 2020; Jonathan Stempel, "This Land is Your Land" Suit Dismissed by U.S. Judge', Reuters, 29 February 2020; and Kaylee McGhee, 'It's Not Your Land, Says Woody Guthrie's Estate', Washington Examiner, 5 March 2020.

131 Saint-Amour et al v. The Richmond Organization, Inc. (TRO Inc.), (2020) No. 1:2016cv04464.

132 Saint-Amour et al v. The Richmond Organization, Inc. (TRO Inc.), (2020) No. 1:2016cv04464.

133 Saint-Amour et al v. The Richmond Organization, Inc. (TRO Inc.), (2020) No. 1:2016cv04464.

134 Klinger v. Conan Doyle Estate Ltd. 988 F. Supp. 2d. 879 (2013); Matthew Rimmer, 'Free Sherlock Holmes: The Copyright Battle of Baker Street', The Conversation, 30 September 2013, and Klinger v. Conan Doyle Estate Ltd. 755 F 3d. 496 (2014).

135 Klinger v. Conan Doyle Estate Ltd. 755 F 3d. 496 at 503 (2014).

136 Klinger v. Conan Doyle Estate Ltd. 755 F 3d. 496 at 497 (2014). 
this devastating defeat, the Conan Doyle Estate have brought legal action against a Sherlock Holmes sequel featuring the sister of Sherlock Holmes. ${ }^{137}$

The Association of Research Libraries and various other knowledge-based organisations expressed concerns in 2013 about the impact of a copyright term extension. ${ }^{138}$ The organisations commented:

There is no benefit to society of extending copyright beyond the 50 years mandated by the WTO. While some TPP countries, like the United States, Mexico, Peru, Chile, Singapore or Australia, already have life +70 (or longer) copyright terms, there is growing recognition that such terms were a mistake, and should be shortened, or modified by requiring formalities for the extended periods. ${ }^{139}$

The submission warned that extended copyright terms resulted in orphan works - where it was difficult to locate the author of cultural items. Moreover, the long copyright terms would also raise transaction costs in getting access to vintage copyright works. The submission concluded: 'Life +70 is a mistake, and it will be an embarrassment to enshrine this mistake into the largest regional trade agreement ever negotiated. ${ }^{\prime 40}$

In 2012, the Electronic Frontier Foundation highlighted that a major concern was that the ' $T P P$ seeks to propagate the excessive copyright terms currently found in American copyright legislation, and will become yet another tool of the second enclosure movement: "the enclosure of the intangible commons of the mind." 141 The group warned that "these terms are detrimental to creativity and innovation and only serve to benefit the major record and movie production companies who lobbied for them in the U.S.' ${ }^{142}$ The group feared that such trade measures were designed to circumvent the usual scrutiny associated with copyright law reform in national parliaments: "Making these terms part of trade agreements is part of a general move towards "forum shifting" and "policy laundering" of the IP policy discussion away from places where there is at least some requirement for public input and transparency, such as Congress.' ${ }^{143}$

Libraries, public archives and educational institutions have been concerned about the high cost of the copyright term extension. ${ }^{144}$ They warned: 'This transfer of welfare in favour of large corporate copyright owners will come at the cost of those who depend upon access to copyright works that would otherwise be in the public domain - libraries, students, artists writers, and millions of other people. ${ }^{145}$

137 Eriq Gardner, 'Conan Doyle Estate Sues Netflix over Coming Movie about Sherlock Holmes' Sister', Hollywood Reporter, 24 June 2020.

${ }_{138}$ American Archivists and others, 'Letter to TPP Negotiators on the Copyright Term', 6 December 2013.

139 Ibid.

140 Ibid.

141 Carolina Rossini and Yana Welinder, 'All Nations Lose with TPP's Expansion of Copyright

Terms', Electronic Frontier Foundation, 8 August 2012.

142 Ibid.

143 Ibid.

144 Association for Progressive Communications, and others, 'Copyright Term Letter', 9 July 2014.

145 Ibid. 
The Creative Commons movement has been distressed about the copyright term extension, calling the measure 'unnecessary and unwarranted'. ${ }^{146}$ The Creative Commons observed: 'There is no logical reason to increase the term of copyright: an extension would create a tiny private benefit at a great cost to the public. ${ }^{147}$ The Creative Commons warned that 'the ratification of the TPP would limit the size and diversity of materials that are available for everyone to build on, from art, music and other expressive cultural creations, to education resources to scientific research'. ${ }^{148}$ The Creative Commons added that the copyright term extension 'will also exacerbate the problem of orphan works, because those works would have entered into the public domain because their copyrights had expired'. ${ }^{149}$ Moreover, the Creative Commons movement maintains that the copyright term extension would cost the public hundreds of millions of dollars each year.

Wikimedia - the policy body in charge of Wikipedia - has expressed its concerns about the impact of the copyright term extension upon the creation and sharing of free knowledge across the Pacific Rim:

Unfortunately, TPP would extend copyright terms at a minimum of the author's life plus 70 years, eating into the public domain. This cements a lengthy copyright term in countries where it already exists like Australia, the US, and Chile. But it's especially worrisome for the public domain in countries like Japan, New Zealand, and Canada that now have shorter copyright terms because it means that a great number of works will not be free to use, remix, and share for another 20 years. ${ }^{150}$

Wikimedia observed that Wikipedia benefited from having millions of artistic works with public domain images, which could be shared without copyright restrictions. Wikimedia commented: 'TPP is a problematic treaty because it harms the public domain and our ability to create and share free knowledge.' ${ }^{151}$

KEI has expressed concerns about the impact of the copyright term extension of the TPP upon the public domain and the intellectual commons. ${ }^{152}$ The group has also been concerned about the problem of orphan works - where authorship cannot be determined because the author is lost, missing or deceased. There was initially concern about the TPP's effect on the policy flexibilities available to address the problem of orphan works, by placing limitations on statutory remedies. ${ }^{153}$ The final text does nothing in the way of addressing the risks of orphan works through a copyright term extension across the Pacific Rim.

The civil society organisation Public Knowledge was also concerned about the impact of the copyright term extension, warning: 'The agreement must not reduce or otherwise diminish the

146 Creative Commons, 'The Trans-Pacific Partnership Would Harm User Rights and the Commons', 16 November 2015.

147 Ibid.

148 Ibid.

149 Ibid.

150 Wikimedia, 'What's the TPP? The Problematic Partnership', Medium, 3 February 2016.

151 Ibid.

152 Knowledge Ecology International, 'Copyright Issues in the TPP', 22 July 2015.

153 Knowledge Ecology International, 'US Copyright Office Proposes Limits on Damages, Injunctions, for Orphan Works, Contradicting TPP Language', 4 June 2015. 
public domain.' ${ }^{154}$ In its opinion, 'a robust and accessible public domain benefits society and the economy by enhancing education, research, and the arts'. ${ }^{155}$ Moreover, Public Knowledge said that a rich public domain 'fuels job creation and economic growth, and must be protected in our trade agreements abroad'. ${ }^{156}$ Public Knowledge concluded: 'The TPP must therefore not promote the lengthening of already long copyright terms, or allow restrictions upon the sharing of scientific discoveries, products or principles, of nature, or abstract ideas. ${ }^{\text {'57 }}$

Former Clinton Labor Secretary Robert B. Reich regrets the Clinton Administration's decision to pass a copyright term extension. ${ }^{158} \mathrm{He}$ comments that 'the result [of the copyright term extension] is higher corporate profits, higher costs to consumers, and less access for everyone'. ${ }^{159}$ Reich comments that the copyright term extension has not been an incentive for further creative production: 'This reorganization of the market will not spur more creativity from Walt Disney or the brothers Gershwin, since they are no longer with us. ${ }^{160}$ Reich also highlights the ability of copyright owners to contest conflicts over the boundaries between copyright law and the public domain. He contended that 'the large corporate owners of copyrights aggressively fight in court to extend their long-extended copyrights, adding to their bottom lines and their economic clout'. ${ }^{161}$ Reich also highlighted the ability of intellectual property owners to push for further political concessions: 'Due to the increasing wealth and political influence of large corporations, as well as the subtlety and complexity of the contours of intellectual property, these political decisions have tended to enlarge and entrench that wealth and power.' ${ }^{162}$

In 2019, the Internet Archive and the Creative Commons celebrated the 'Grand Re-opening of the Public Domain'. ${ }^{163}$ Cory Doctorow reflected upon this watershed moment: 'The existence of a robust public domain is one of the ways we can still escape the grip of these oligarchic firms that command a larger and larger percentage of the money that our works generate.'164 In 2019, the New York Public Library made available a wide range of works which had fallen into the public domain because of a lack of renewal of copyright registration. ${ }^{165}$ Such work has been made available on Project Gutenberg and the Hathi Trust.

154 Michael Baak, 'How the Trans-Pacific Partnership Jeopardizes Fair Use', Public Knowledge, 24 September 2015.

155 Ibid.

156 Ibid.

157 Ibid.

158 Robert B. Reich, Saving Capitalism: For the Many, Not the Few, New York: Alfred A. Knopf, 2015.

159 Ibid., 27.

160 Ibid., 27.

161 Ibid., 28.

162 Ibid., 28.

163 Internet Archive, ‘A Grand Re-opening of the Public Domain', YouTube, 25 January 2019.

164 Joe Kukura, 'Copyrights and Wrongs', San Francisco Weekly, 2 January 2019.

165 Cory Doctorow, 'Data-Mining Reveals that $80 \%$ of Books Published 1924-63 Never Had Their Copyrights Renewed and Are Now in the Public Domain', Boing Boing, 1 August 2019; Matthew Gault, 'Millions of Books Secretly in the Public Domain Can Be Downloaded for Free', Motherboard, 7 August 2019. 


\section{Canada}

\section{A. Objectives}

The Supreme Court of Canada has articulated a sophisticated vision of the nature and role of copyright law in a string of cases. In Théberge v. Galerie d'Art du Petit Champlain Inc., Binnie J of the Supreme Court of Canada discussed the purpose of copyright law in Canada:

Excessive control by holders of copyrights and other forms of intellectual property may unduly limit the ability of the public domain to incorporate and embellish creative innovation in the long-term interests of society as a whole, or create practical obstacles to proper utilization. This is reflected in the exceptions to copyright infringement enumerated in ss. 29 to 32.2, which seek to protect the public domain in traditional ways such as fair dealing for the purpose of criticism or review and to add new protections to reflect new technology, such as limited computer program reproduction and 'ephemeral recordings' in connection with live performances. ${ }^{166}$

In the case of CCH Canadian Ltd. v. Law Society of Upper Canada, McLachlan CJ noted that, in the Théberge case, 'this Court stated that the purpose of copyright law was to balance the public interest in promoting the encouragement and dissemination of works of the arts and intellect and obtaining a just reward for the creator'. ${ }^{167}$

The Supreme Court of Canada has further elaborated this philosophical position in the 'Pentalogy' of copyright cases. ${ }^{168}$ Abraham Drassinower has considered the philosophical underpinnings of this approach to copyright law by the Supreme Court of Canada in his book, What's Wrong with Copying? ${ }^{169}$ Canadian researchers have also further considered these landmark decisions. ${ }^{170}$

Professor Blayne Haggart has maintained that there is a need for Canada to consider larger cultural costs in negotiating trade agreements, reflecting:

An IP policy that is appropriate for an IP superpower such as the United States is not necessarily appropriate for a country such as Canada. Not costing out the short- or long-term costs of these agreements means that considering how these provisions affect the ability of Canadians to innovate and access knowledge becomes a secondary issue. The potential consequences of this lack of attention are

166 Théberge v. Galerie d'Art du Petit Champlain Inc., [2002] 2 SCR 336, 2002 SCC 34 (CanLII).

167 CCH Canadian Ltd. v. Law Society of Upper Canada, [2004] 1 SCR 339, 2004 SCC 13 (CanLII).

168 Entertainment Software Association v. Society of Composers, Authors and Music Publishers of Canada, 2012 SCC 34 (12 July 2012); Rogers Communications Inc. v. Society of Composers, Authors and Music Publishers of Canada, 2012 SCC 35 (12 July 2012); Re: Sound v. Motion Picture Theatre Associations of Canada, 2012 SCC 38 (12 July 2012); Society of Composers, Authors and Music Publishers of Canada v. Bell Canada, 2012 SCC 36 (12 July 2012); and Alberta (Education) v. Canadian Copyright Licensing Agency (Access Copyright), 2012 SCC 37 (12 July 2012).

169 Abraham Drassinower, What's Wrong with Copying? Cambridge (MA): Harvard University Press, 2015.

${ }_{170}$ Carys Craig, Copyright, Communication and Culture: Towards a Relational Theory of Copyright Law, Cheltenham (UK) and Northampton (MA): Edward Elgar Publishing, 2011; Michael Geist (ed.), The Copyright Pentalogy: How the Supreme Court of Canada Shook the Foundations of Canadian Copyright, Ottawa: University of Ottawa Press, 2013; and Rosemary Coombe, Darren Wershler and Martin Zeilinger (ed.), Dynamic Fair Dealing: Creating Canadian Culture Online, Toronto: University of Toronto Press, 2014. 
dire, including, namely, deals that negatively affect the country's capacity to produce the innovative knowledge needed to ensure long-term economic prosperity. ${ }^{171}$

He has emphasised the need for hard-headed empirical analysis of economic agreements in terms of the global economy.

\section{B. TPP and the copyright term}

In Canada, previous efforts to extend the copyright term have been rebuffed by an active civil society and intellectual property community. The estate of Lucy Maud Montgomery made an unsuccessful attempt to obtain a copyright term extension in relation to the works of the author of Anne of Green Gables. ${ }^{172}$

Professor David Lametti - who has since become the Attorney-General in Justin Trudeau's government - has made an academic argument for shorter copyright terms, in light of the commercial life of copyright works. ${ }^{173} \mathrm{He}$ also maintains that it should be possible to vary the terms of copyright according to the subject matter. Moreover, Lametti has made the case for a registration system in respect of copyright works.

Professor Michael Geist of the University of Ottawa laments that in domestic politics Canada has resisted a copyright term extension. ${ }^{174}$ Moreover, the copyright term extension in the TPP goes against repeated rejections of a copyright term extension in Canadian politics:

From a policy perspective, the decision to maintain the international standard of life plus 50 years is consistent with the evidence that term extension creates harms by leaving Canadians with 20 years of no new works entering the public domain with virtually no gains in terms of new creativity. In other words, in a policy world in which copyright strives to balance creativity and access, term extension does not enhance creativity but it does restrict access. ${ }^{175}$

Geist warned that 'the damage caused by the term extension involves more than just higher costs to consumers and educational institutions' ${ }^{176}$ He emphasised that the decision also creates 'a massive blow to access to Canadian heritage'. ${ }^{177}$ Geist observed: 'Canadian publishers such as Broadview Press, an independent academic publisher that has been a vocal proponent of copyright, warned about the dangers of the term extension to its business and the academic community last fall. ${ }^{178} \mathrm{He}$ commented that the copyright term extension would mean that work by leading Canadian authors - such as Margaret Laurence, Gabrielle Roy, Marian Engel, Marshall McLuhan and Donald Creighton - would not fall into the public domain for decades. Moreover, he observed: 'In addition to Canadian authors, there are many well-known interna-

171 Blayne Haggart, 'Modern Free Trade Agreements Are Not About Free Trade', Centre for International Governance Innovation, 11 April 2017.

172 Andrea Slade, 'Guarding a Cultural Icon: Concurrent Intellectual Property Regimes and the Perpetual Protection of Anne of Green Gables in Canada' (2011) 56 (4) McGill Law Journal 1011-55.

173 David Lametti, 'Coming to Terms with Copyright' in Michael Geist (ed.), In The Public Interest: The Future of Canadian Copyright Law, Toronto: Irwin Law, 2005, 480-516.

174 Michael Geist, 'The Trouble with the TPP: Copyright Term Extension', University of Ottawa, 6 January 2016.

175 Ibid.

176 Ibid.

177 Ibid.

178 Ibid. 
tional figures that will be kept out of the public domain such as John Steinbeck, Martin Luther King, Andy Warhol, Woody Guthrie, and Elvis Presley.' ${ }^{179}$

Professors Ariel Katz and Liran Kandinov of the University of Toronto raised constitutional concerns about a copyright term extension in Canada under the TPP. ${ }^{180}$ The pair commented that 'adding 20 more years of copyright protection is more than just bad policy; it might well create an unconstitutional limitation on our freedom of expression'. ${ }^{181}$ Katz and Kandinov commented: 'Adding 20 more years of exclusivity will restrict both our right to convey meaning through our own expression, as well as our right to obtain information and use the expression of others.' 182 The pair emphasised: 'The Canadian Charter of Rights and Freedoms protects both, and thus places on the government the burden to justify the limitations. ${ }^{183}$ Katz and Kandinov conclude that 'the Charter constrains the ability of all governments to limit our fundamental rights and freedoms and to trade them away in return for some economic or political gains the government deems expedient.' ${ }^{184}$

There was significant debate before the Standing Committee on International Trade about the prospect of a copyright term extension in Canada under the TPP. ${ }^{185}$ There was a stark difference in position between stakeholders. In addition to Michael Geist expressing his concerns, the Canadian Association of Research Libraries warned that a copyright term extension in Canada would make much of the country's cultural history inaccessible to the public, and could have harmful effects for Canada's knowledge economy. ${ }^{186}$ Open Media also observed that a copyright term extension in Canada would make it more difficult to create works in Canada. Taking an in-between position, Professor Ysolde Gendreau from the University of Montreal argued that the trend of the copyright term extension was well developed. She observed that 'there are far more important issues in copyright to deal with'. ${ }^{187}$

Professor Margaret Ann Wilkinson and Tierney Deluzio have explored the particular issues about copyright term in respect of photographs. ${ }^{188}$

There were, though, a few supporters of the copyright term extension. The Canadian Music Publishers Association and the Society of Composers, Authors and Music Publishers of Canada supported a copyright term extension. ${ }^{189}$

179 Ibid.

180 Ariel Katz and Liran Kandinov, ‘TPP Trades Away Our Constitutional Rights', Toronto Star, 29 October 2015.

181 Ibid.

182 Ibid.

183 Ibid.

184 Ibid.

185 Standing Committee on International Trade, The Trans-Pacific Partnership Agreement: Benefits and Challenges for Canadians, House of Commons, 42nd Parliament, 1st Session, Canadian Parliament, April 2017.

186 Ibid., 55.

187 Ibid., 66.

188 Margaret Ann Wilkinson and Tierney GB Deluzio, 'The Term of Copyright Protection in Photographs'. (2015) 31 Canadian Intellectual Property Review 95-109.

189 Standing Committee on International Trade, The Trans-Pacific Partnership Agreement: Benefits and Challenges for Canadians, House of Commons, 42nd Parliament, 1st Session, Canadian Parliament, April 2017, 56-7. 
The report of the Standing Committee on International Trade was rather cursory in its analysis of the copyright term extension in Canada, and did not extend beyond a summary of competing submissions on the topic.

During discussions over the TPP-11/CPTPP, Justin Trudeau's Canadian government called for suspension over a range of controversial provisions, including the clause on the copyright term extension. However, the government then retreated from this stance during the negotiations over the USMCA.

\section{Copyright term extension and the $U S M C A$}

However, Justin Trudeau's Canadian government abandoned this high ground as part of negotiations over the revision of NAFTA. As part of the USMCA, Canada will have to abide by longer standards of copyright protection. Article 20.H.7 of USMCA deals with 'Term of Protection for Copyright and Related Rights' and provides:

Each Party shall provide that in cases in which the term of protection of a work, performance or phonogram is to be calculated:

(a) on the basis of the life of a natural person, the term shall be not less than the life of the author and 70 years after the author's death; and

(b) on a basis other than the life of a natural person, the term shall be:

(i) not less than 75 years from the end of the calendar year of the first authorized publication of the work, performance or phonogram; or

(ii) failing such authorized publication within 25 years from the creation of the work, performance or phonogram, not less than 70 years from the end of the calendar year of the creation of the work, performance or phonogram. ${ }^{190}$

There has been significant discussion of the long-term impact of the copyright term extension in Canada.

The Canadian singer-songwriter Bryan Adams has been critical of proposals for a copyright term extension, cautioning:

Canada is now more or less duty-bound to increase copyright protection by 20 years, to 'life +70 '. Extending the duration of copyright essentially enriches large firms of intermediaries. It does not put money in the pockets of most creators. Economists argue that copyright already lasts too long. ${ }^{191}$

Adams argues that Parliament 'should do something to ensure that more of the benefits from copyright extension flow to creators' ${ }^{192}$ In his view, 'Granting the right of termination is an interesting and effective way to balance copyright duration with creators' continued remuneration'. ${ }^{193}$

190 Article 20.H.7 of the United States-Mexico-Canada Agreement 2018.

191 Bryan Adams with Mario Bouchard, 'It's About Time! Terminating Copyright Assignments to Preserve Creator's Rights', Standing Committee on Canadian Heritage, 2018.

192 Ibid.

193 Ibid. 
KEI has been critical of the copyright term extension in the USMCA. ${ }^{194}$ In its view, the copyright term extension is 'excessive and harmful'. ${ }^{195} \mathrm{KEI}$ reflects upon the economics of the copyright term extension:

Extended copyright terms do not benefit authors, and there is no policy reason to provide income to heirs of authors for more than 50 years after the death of authors. Those people can get jobs like the rest of us. The extended term is also a tax on performers, who then have to share their incomes with persons who did not write works or perhaps even know the authors, more than a half century after the death of an author. ${ }^{196}$

\section{KEI argued:}

The extended copyright term also creates extensive damage to society by creating millions of orphaned copyrighted works, an issue discussed in endless academic articles and government policy papers, that USTR officials should have read and taken into consideration, instead of doing the bidding of lobbyists representing heirs of dead authors or corporations seeking to extend protections over works more than a half century beyond anyone was paid to create them. ${ }^{197}$

Given Canada's capitulation on the issue of the copyright term extension in the USMCA, there has also been discussion as to whether the suspension on the copyright term extension in TPP-11 will be lifted in the future.

\section{Australia}

\section{A. Objectives}

The High Court of Australia has discussed the nature, role and function of copyright law in a series of cases. In the 2009 IceTV case, French CJ, Crennan and Kiefel JJ discussed the social contract behind Australian copyright law:

Copyright legislation strikes a balance of competing interests and competing policy considerations. Relevantly, it is concerned with rewarding authors of original literary works with commercial benefits having regard to the fact that literary works in turn benefit the reading public.

In both its title and opening recitals, the Statute of Anne of 1709 echoed explicitly the emphasis on the practical or utilitarian importance that certain seventeenth century philosophers attached to knowledge and its encouragement in the scheme of human progress. The 'social contract' envisaged by the Statute of Anne, and still underlying the present Act, was that an author could obtain a monopoly, limited in time, in return for making a work available to the reading public. ${ }^{198}$

The judges recognised that there was often disagreement as to where the balance should be struck in respect of copyright law. Nonetheless, the judges held that copyright law should

194 Knowledge Ecology International, 'On the United States-Mexico-Canada Agreement: Likely Impact on the U.S. Economy and on Specific Industry Sectors Investigation (No.TPA-105-003)', 31 October 2018.

195 Ibid., 12.

196 Ibid., 13.

197 Ibid., 13.

198 IceTV Pty Limited v. Nine Network Australia Pty Limited [2009] HCA 14239 CLR 458; 83 ALJR $585 ; 254$ ALR 386 
help support a broader public domain: 'Copyright, being an exception to the law's general abhorrence of monopolies, does not confer a monopoly on facts or information because to do so would impede the reading public's access to and use of facts and information.' 199

In the 2012 case of Phonographic Performance Company of Australia Limited v. Commonwealth of Australia, the High Court of Australia rejected a constitutional challenge to compulsory licensing provisions. ${ }^{200}$ Crennan and Kiefel JJ held that the

recurrent legislative balancing of the competing interests of copyright owners and the public does not support absolute propositions such as that copyright is an inherently unstable right, or that reductions in the exclusive rights to do acts within a copyright are always permissible adjustments under $\mathrm{s}$ 51 (xviii) of the Constitution which do not attract the guarantee under s 51(xxxi). ${ }^{201}$

The judges observed: 'Exceptions to infringement, which include fair dealings or fair uses and compulsory licence provisions, constitute qualifications of or limitations upon a copyright owner's exclusive rights to do acts within the copyright, during the term of a copyright'. ${ }^{202}$ The judges stressed: 'In each case, such provisions reflect a specific public interest in obtaining access to the subject matter of copyright on some reasonable basis. ${ }^{203}$

In the plain packaging of tobacco products dispute, the High Court of Australia also discussed more generally the philosophical objectives of copyright law in Australia. ${ }^{204}$ French CJ commented:

Copyright is defined by reference to exclusive rights of, inter alia, reproduction and publication of works and subject matter other than works. It is classified in the Copyright Act as 'personal property' which is transmissible by 'assignment, by will and by devolution by operation of law.' Registered trade marks, designs, patents and copyright in works and other subject matter give rise to, or constitute, exclusive rights which are property to which s 51(xxxi) of the Constitution can apply. They are all rights which are created by statute in order to serve public purposes. They differ in their histories, their character and the statutory schemes which make provision for them...It is a common feature of the statutory rights asserted in these proceedings that they are negative in character. ${ }^{205}$

\footnotetext{
199 IceTV Pty Limited v. Nine Network Australia Pty Limited [2009] HCA 14239 CLR 458; 83 ALJR 585; 254 ALR 386

200 Phonographic Performance Company of Australia Limited v. Commonwealth of Australia [2012] HCA 8246 CLR 561; 86 ALJR 335; 286 ALR 61.

201 Phonographic Performance Company of Australia Limited v. Commonwealth of Australia [2012] HCA 8246 CLR 561; 86 ALJR 335; 286 ALR 61.

202 Phonographic Performance Company of Australia Limited v. Commonwealth of Australia [2012] HCA 8246 CLR 561; 86 ALJR 335; 286 ALR 61.

${ }_{203}$ Phonographic Performance Company of Australia Limited v. Commonwealth of Australia [2012] HCA 8246 CLR 561; 86 ALJR 335; 286 ALR 61.

${ }^{204}$ JT International SA v. Commonwealth; British American Tobacco Australasia Ltd v. Commonwealth [2012] HCA 43 (5 October 2012); Matthew Rimmer, 'The High Court and the Marlboro Man: The Battle Over The Plain Packaging of Tobacco Products', in Tania Voon, Andrew Mitchell, and Jonathan Liberman (eds), Regulating Tobacco, Alcohol and Unhealthy Foods: The Legal Issues, London: Routledge, 2013, 337-60; and Matthew Rimmer, 'Plain Packaging for the Pacific Rim: The Trans-Pacific Partnership and Tobacco Control' in Tania Voon (ed.), Trade Liberalisation and International Co-operation: A Legal Analysis of the Trans-Pacific Partnership Agreement, Cheltenham (UK) and Northampton (MA): Edward Elgar, 2013, 75-105.

205 JT International SA v. Commonwealth; British American Tobacco Australasia Ltd v.
} Commonwealth [2012] HCA 43 (5 October 2012) [34]-[36]. 
There was a strong emphasis in the decision that the role of intellectual property is to promote broad public policy objectives - and not merely serve as an instrument of private profit.

The High Court of Australia has also considered the relative equilibrium of Australian copyright law in a set of other cases. ${ }^{206}$

The Australian Law Reform Commission highlighted a series of framing principles for copyright law reform. ${ }^{207}$ The first principle was the importance of acknowledging and respective authorship and creation. The second principle focused on maintaining incentives for creation and dissemination. The third principle talked about promoting fair access to content. The fourth principle was that rules should be flexible, clear and adaptive. The fifth principle was that there was a need that rules be consistent with international obligations.

Moreover, the Australian Law Reform Commission stressed that Australian copyright law should be contextualised in terms of the digital economy, innovation and productivity. There was a need to contemplate the role of copyright law in the digital economy, and the opportunities for innovation leading to national economic and cultural development created by the emergence of new digital technologies. The Australian Law Reform Commission also observed that copyright law had a key role in respect of consumer rights and competition policy. The inquiry also acknowledged that copyright law directly affects a broad range of cultural activity, and raised larger implications in respect of cultural policy.

The Harper Review expressed concerns that there was a lack of guiding objectives to Australia's negotiation of intellectual property in trade agreements: 'The Panel is concerned that Australia has no overarching IP policy framework or objectives guiding changes to IP protection or approaches to IP rights in the context of negotiations for international trade agreements.' 208

The Productivity Commission was likewise dismayed by the lack of policy coherence in respect to Australia's intellectual property regime:

Clear articulation of a policy objective would help to ensure that all elements of the IP system are consistent and 'pulling in the same direction', while providing regulators, government and the judiciary a common understanding of what the IP system is meant to achieve. But the Commission has found little consensus as to what the objective of the IP system should be, beyond some broad themes. ${ }^{209}$

The Productivity Commission contended that 'the IP system's overarching objective should be to recognise and encourage the creation of new and valuable ideas and innovations in a way that maximises the wellbeing of all Australians'. ${ }^{210}$ The Productivity Commission identified four principles that were essential to a balanced and well-functioning intellectual property regime - 'effectiveness', 'efficiency', 'adaptability' and 'accountability'.

206 Network Ten Pty Limited v. TCN Channel Nine Pty Limited [2004] HCA 14; Stevens v. Kabushiki Kaisha Sony Computer Entertainment [2005] HCA 58; Burge v. Swarbrick [2007] HCA; and Roadshow Films Pty Ltd v. iiNet Limited [2012] HCA 16.

207 Australian Law Reform Commission, Copyright and the Digital Economy (ALRC Report 122), Sydney: The Australian Law Reform Commission, 13 February 2014, 41-56.

${ }_{208}$ Ian Harper, Peter Anderson, Sue McCluskey and Michael O’Bryan, Competition Policy Review: Final Report, Canberra: Australian Government, March 2015, 41.

209 Productivity Commission, Intellectual Property Arrangements, Melbourne: Productivity Commission, Report No. 78, 2016, 54.

210 Ibid., 54. 


\section{B. Copyright term extension under AUSFTA}

The history of the copyright term in Australia is a long and convoluted story. ${ }^{211}$

In 2004, the Australian government controversially agreed to a copyright term extension as part of the Australia-United States Free Trade Agreement 2004. ${ }^{212}$

The Australian Productivity Commission considered a litany of the problems with an extended copyright term in its Draft Report and Final Report on Intellectual Property arrangements in $2016 .^{213}$

The Productivity Commission highlights that Australia is a net importer of copyright works. The Productivity Commission noted that 'Australia now imports close to $\$ 9$ million in copyright-protected goods and services - around 2.4 times more than it exports' ${ }^{214}$ In its overview of the topic, the Productivity Commission highlights that the copyright term in Australia is excessive and imposes costs:

Few, if any, creators are motivated by the promise of financial returns long after death, particularly when the commercial life of most works is less than 5 years. Overly long copyright terms impose costs on the community. Empirical work focussing on Australia's extension of copyright protection from life plus 50 years to life plus 70 years (a requirement introduced as part of the Australia-United States Free Trade Agreement) estimated that an additional 20 years protection would result in net transfers from Australian consumers to foreign rights holders of around $\$ 88$ million per year. But these are likely to be a fraction of the full costs of excessive copyright protection. The retrospective application of term extension exacerbates the cost to the community, providing windfall gains to copyright holders with no corresponding benefit. ${ }^{215}$

The Productivity Commission highlights the transaction costs involved with extended copyright terms: 'Long periods of copyright protection, coupled with automatic application and no registration requirements, results in many works being "orphaned" - protected by copyright but unusable by libraries, archives and consumers because the rights holder cannot be identified.'216 Moreover, the Productivity Commission observes: 'Many other works are

211 For a good history of the copyright term in Australia, see: Catherine Bond and Graham Greenleaf, 'Copyright Duration in Australia: 1869 to 2014' (2015) 25 Australian Intellectual Property Journal $155-78$.

212 For broader commentary on the Australia-United States Free Trade Agreement 2004, see: Jock Given, America's Pie: Trade and Culture after 9/11, Sydney: University of New South Wales Press, 2003; Linda Weiss, Elizabeth Thurbon and John Mathews, How to Kill a Country: Australia's Devastating Trade Deal with the United States, Sydney: Allen \& Unwin, 2004; Ann Capling, All the Way with the USA: Australia, the US and Free Trade, Sydney: University of New South Wales Press, 2005; Christopher Arup, 'The United States-Australia Free Trade Agreement - The Intellectual Property Chapter' (2004) 15 (4) Australian Intellectual Property Journal 205; and Christopher Moore, 'Creative Choices: Changes to Australian Copyright Law and the Future of the Public Domain' (2005) 114 Media International Australia 71-82; and Matthew Rimmer, 'Robbery under Arms: Copyright Law and the Australia-United States Free Trade Agreement 2004' (2006) 11 (3) First Monday.

213 Productivity Commission, Intellectual Property Arrangements - Draft Report, Melbourne: Productivity Commission, 2016; and Productivity Commission, Intellectual Property Arrangements, Melbourne: Productivity Commission, Report No. 78, 2016.

214 Productivity Commission, Intellectual Property Arrangements, Melbourne: Productivity Commission, Report No. 78, 2016, Box 4.1.

215 Ibid., 17.

216 Ibid., 17. 
also unavailable to consumers once outside of their window of commercial exploitation.'217 The Productivity Commission comments that 'A number of studies have attempted to estimate a duration of protection where the benefits to holders are matched by the costs to users'. ${ }^{218}$ The Productivity Commission summarises such work: 'These studies find that a term of around 25 years enables rights holders to generate revenue comparable to what they would receive in perpetuity (in present value terms), without imposing onerous costs on consumers. ${ }^{219}$

The Productivity Commission reviewed a variety of studies, which have attempted to estimate the 'optimal' duration of copyright protection. ${ }^{220}$ The Productivity Commission considers the work of leading law and economics specialists:

Landes and Posner (2002) argue a term of around 25 years enables rights holders to generate revenue comparable to what they would receive in perpetuity (in present value terms), without imposing onerous costs on consumers and suggests that a term of around 25 years is sufficient to incentivise creative effort. However, this is only an indicative period because the lower the discount rate used, the greater the term should be, and the authors used a relatively high real discount rate. In addition, any estimate of optimal term duration must make assumptions about the pattern of demand for the works over time - a difficult task. The truly 'optimal' period may accordingly be more or less than 25 years after creation but it is completely implausible it could ever be 70 years after death. ${ }^{221}$

The Productivity Commission also notes the work of Pollock, who uses an alternative methodology to estimate the optimal length of copyright protection: 'His work suggests a copyright term around 15 years after creation balances the benefits and costs of the system. ${ }^{222}$ The Productivity Commission concluded: 'Australia has no unilateral capacity to alter copyright terms, but can negotiate internationally to lower the copyright term.' 223

Draft Finding 4.1 lamented that 'Australia's copyright system has expanded over time, often with no transparent, evidence based policy analysis demonstrating the need for, or quantum of, new rights'. ${ }^{224}$ Draft Finding 4.2 observed: 'While hard to pinpoint an optimal copyright term, a more reasonable estimate would be closer to 15 to 25 years after creation; considerably less than 70 years after death.' ${ }^{225}$ Draft Recommendation 4.1 was that 'The Australian Government should amend the Copyright Act 1968 (Cth) so the current terms of copyright protection apply to unpublished works'.226

Copyright owners - particularly from the publishing industry - rather wilfully misinterpreted the work of the Productivity Commission, suggesting that the body had called for a reduction in the copyright term. ${ }^{227}$ For instance, award-winning author Richard Flanagan

217 Ibid., 17.

218 Ibid., 17.

219 Ibid., 17.

220 Ibid., 116.

221 Ibid., 116.

222 Ibid., 117.

223 Ibid., 117.

224 Ibid., 29.

225 Ibid., 29

226 Ibid., 30.

227 Steph Harmon and Lucy Clark, 'Magda Szubanski May Leave Australia if Changes to Book Industry Go Ahead', The Guardian, 20 May 2016. 
alleged that the Productivity Commission wanted to reduce the term of copyright to 15-25 years. ${ }^{228}$ He maintained:

So Mem Fox has no rights in Possum Magic. Stephanie Alexander has no rights in A Cook's Companion. Elizabeth Harrower has no rights in The Watch Tower. John Coetzee has no rights in his Booker winning Life and Times of Michael K. Nor Peter Carey to The Kelly Gang, nor Tim Winton to Cloudstreet. Anyone can make money from these books except the one who wrote it. ${ }^{229}$

Such an allegation is deeply misleading. Quite clearly, the Draft Report of the Productivity Commission makes no such recommendation regarding the copyright term. Likewise, the coalition government under Malcolm Turnbull had articulated no proposal to abridge the copyright term.

Economist Peter Martin commented that the Productivity Commission was aware that Australia was locked into extended copyright terms by successive trade agreements. ${ }^{230} \mathrm{He}$ commented upon the discussion of the inquiry:

What it wanted to do was to wind back Australia's 120 years plus copyright terms. It reckons 15 to 25 years is all that's needed. It says the average commercial life of a book is 1.4 to 5 years. Beyond that, the harm copyright does by locking things up outweighs any conceivable benefit to the authors in extra income. But it couldn't. ${ }^{231}$

Martin observed that the inquiry had highlighted the high economic costs of copyright term extensions. He also noted that the inquiry had stressed that the Australian government should not try to make commitments on copyright law without an initial assessment of the costs and benefits. Martin noted that the Productivity Commission nonetheless acknowledged that it would be difficult to unravel past copyright term extensions, because they were embedded in trade agreements.

The Productivity Commission reiterated its concern about the copyright term extension in the Trade and Assistance Review for 2014-15.232

The final report of the Productivity Commission on intellectual property arrangements ruefully reiterates its deep concerns about the economic impact of the copyright term extension in Australia. ${ }^{233}$ The Productivity Commission was disappointed that its draft report had been misrepresented by copyright industries:

Despite many claims to the contrary, the Commission is not recommending any changes to the length of copyright term - doing so would require amendments to international agreements such as the Berne

${ }^{228}$ Simon Thomsen, 'Australia's Greatest Author Went Berserk over Copyright Changes, Saying Malcolm Turnbull Wants to Destroy the Book Industry', Business Insider, 20 May 2016.

229 Ibid.

230 Peter Martin, 'The Productivity Commission's Hands Were Tied on Copyright', The Sydney Morning Herald, 29 April 2016.

231 Ibid.

232 Productivity Commission, Trade and Assistance Review 2014-2015, Melbourne: Productivity Commission, 2016, 50.

233 Productivity Commission, Intellectual Property Arrangements, Melbourne: Productivity Commission, Report No. 78, 2016, 103-34. 
Convention, TRIPS and AUSFTA. But even within the limits of these agreements, there is scope to do more. ${ }^{234}$

The Final Finding 4.1 observed that 'the scope and term of copyright protection in Australia has expanded over time, often with no transparent evidence-based analysis, and is now skewed too far in favour of copyright holders'. ${ }^{235}$ The Final Finding 4.1 noted: 'While a single optimal copyright term is arguably elusive, it is likely to be considerably less than 70 years after death.' ${ }^{236}$ The report noted: 'Governments and academics, here and overseas, continue to explore innovative options for promoting a better balance on copyright term.' ${ }^{237}$

\section{Cooking for copyright}

To a limited extent, the federal government has responded to one of the concerns about copyright term raised by the Productivity Commission. In 2017, the Australian Parliament introduced and passed new copyright legislation, the Copyright Amendment (Disability and Other Measures) Act 2017 (Cth). Among other things, this bill sought to address the anomaly of perpetual copyright protection in respect of unpublished works. Introducing the bill, Minister Paul Fletcher discussed the aims and objectives of the copyright law reform:

Libraries, archives and other cultural institutions hold large volumes of unpublished materials which are an important part of Australia's cultural heritage. Setting a term of protection for unpublished materials will give these institutions greater opportunities to deal with unpublished materials. It will also improve access to important Australian historical and cultural materials that were not previously available to the public. ${ }^{238}$

No doubt there have been greater constitutional concerns and public policy alarms about the effects of perpetual copyright in unpublished works. So such a modest copyright reform by the coalition government is welcome, given the anomalous status of unpublished copyright works in Australia.

\section{New Zealand}

Likewise, the TPP shows little respect for the public policy objectives underlying New Zealand's copyright regime. A report commissioned by the Law Foundation New Zealand and Internet NZ highlighted the disparity between New Zealand's domestic copyright position and the demands of the TPP:

For New Zealand, TPP provisions in this area involves a number of concessions and costs. Despite our 'number 8 wire' ambitions, we remain a net importer of commercial intellectual property. In general, books we learn from, movies we enjoy, and medicines which heal us are purchased overseas. The TPP would extend owners' exclusive rights to these products, meaning that over time and on

\footnotetext{
234 Ibid., 7.

235 Ibid., 31.

236 Ibid., 31.

237 Ibid., 8

238 Hon. Paul Fletcher MP, 'Second Reading Speech on the Copyright Amendment (Disability Access and Other Measures) Bill 2017 (Cth)', Hansard, House of Representatives, 22 March 2017, 2753.
} 
average, we pay more for them. That is a cost to us as consumers, as taxpayers, and as businesses. As one example, extended terms for copyright and certain patents offer immediate benefits to established, mainly overseas owners. New Zealand businesses, particularly where new or growing, benefit less and later. ${ }^{239}$

As a result, the TPP threatened to distort the careful balances and flexibilities built into New Zealand's copyright system.

In 2009 New Zealand's Ministry of Economic Development commissioned a study by Concept Economics and Henry Ergas about the costs and benefits to New Zealand of the copyright proposals in the TPP. ${ }^{240}$ The study made the following estimates in respect of the costs of the copyright term extension:

Based on these net present value results, the Government has estimated the equivalent average annual cost of copyright term extension, over the total period that the extension would take to come into effect. (A discount rate of 7.5\% was used to generate this average real value from the report's net present value results.) This included an additional estimate for the cost of extending copyright on film and television, which Concept Economics did not model, by assuming film and television would incur the same net cost as recorded music. The average cost to New Zealand per year from copyright period changes under TPP was estimated as $\$ 55$ million. This was the mid-point of the range of results reported by the study, which was equivalent to $\$ 51-59$ million per year. ${ }^{241}$

There has been significant debate in New Zealand about the impact of the copyright term extension. ${ }^{242}$

A study commissioned by the Law Foundation New Zealand and Internet NZ expressed concerns about the costs of the copyright term extension for a jurisdiction such as New Zealand. ${ }^{243}$ The report observed:

Extending copyright terms increases profits for holders of existing valuable works. It does not provide a significant incentive to create new works. The difference between a 50-year and a 70 -year term occurs decades after the act of creation, offering a much delayed and highly uncertain financial return for creators. In contrast, holders of existing valuable rights gain a windfall of 20 extra years of sales, with no extra creative output. ${ }^{244}$

The report underlined that a copyright term extension would have an adverse impact on New Zealand's economy and culture.

239 James Ting-Edwards, Melanie Johnson, Judge David Harvey, Debbie Monahan, Kate McHaffie, and Jo Shaw, 'TPPA: Intellectual Property and Information Technology', The Law Foundation New Zealand and Internet NZ, February 2016.

240 Concept Economics, 'Economic Modelling on Estimated Effect of Copyright Term Extension on New Zealand Economy', Ministry of Foreign Affairs and Trade, New Zealand.

241 Ibid.

242 Sharon Brettkelly, 'Who Wins from TPP's Copyright Rules?' Radio New Zealand, 7 October 2015.

243 James Ting-Edwards, Melanie Johnson, Judge David Harvey, Debbie Monahan, Kate McHaffie, and Jo Shaw, 'TPPA: Intellectual Property and Information Technology', The Law Foundation New Zealand and Internet NZ, February 2016.

244 Ibid., 10. 
Internet NZ's chief executive, Jordan Carter, said one of the biggest winners from the copyright term extension was Disney, with its portfolio of legacy works, such as Mickey Mouse. He said the extension meant consumers would have to pay for longer and New Zealand artists would miss out:

A lot of what people do today in the creative sector is remix or reuse. They take old concepts, they reinterpret them for the current day and when something's in the public domain, when it's hit the end of its copyright term, there's no uncertainty about your ability to do that. ${ }^{245}$

Carter commented: 'But when it's still in copyright, you have to try and find out who the owner is, you have to try and find out how much you need to pay, there's less raw material out there for people to riff off and be creative. ${ }^{246} \mathrm{He}$ was concerned that a tougher copyright regime would have a negative impact upon remix culture.

In 2016 debate over implementing legislation for the TPP in the New Zealand Parliament, New Zealand Greens MP Gareth Hughes expressed disquiet about the impact of the copyright term extension upon New Zealand culture. ${ }^{247}$ He lamented: 'So under this legislation, under the copyright provisions of Part 2 of the Trans-Pacific Partnership Agreement Amendment Bill, New Zealand is forced to enact US-style copyright rules, US-style copyright term extensions. ${ }^{248}$ Hughes observed that he had 'researched the impact it is going to have on New Zealand music and New Zealand literature, which would be coming out of copyright, but because this Government is extending terms along the US lines, with none of the corresponding US benefits or protections'. ${ }^{249}$ He commented: 'We are going to see some iconic New Zealand literature such as New Zealand's first gay novel, some incredibly famous music such as the song of the century, Fourmyula's "Nature", stay locked out of the public domain, which means New Zealanders cannot access it. ${ }^{250}$ Hughes concluded: 'We cannot have a richer creative public space, because it is being locked away. ${ }^{251}$

The Hon. Clare Curran, the member of South Dunedin for New Zealand Labour, was critical of the proposal for a copyright term extension under New Zealand law. ${ }^{252}$ She observed:

But one of the things this bill does is that it extends the term of copyright from 50 years to 70 years without any corresponding fairness and balance that acknowledges the digital environment on which our future economy needs to be based, and it trades away something of which we do not get anything back. ${ }^{253}$

\footnotetext{
245 Sharon Brettkelly, 'Who Wins from TPP's Copyright Rules?', Radio New Zealand, 7 October 2015.

246 Ibid.

247 The Hon. Gareth Hughes, 'Parliamentary Debates (Hansard) for Trans-Pacific Partnership Agreement Amendment Bill - In Committee', New Zealand Parliament, 8 November 2016.

248 Ibid.

249 Ibid.

250 Ibid.

251 Ibid.

252 The Hon. Clare Curran, 'Parliamentary Debates (Hansard) for Trans-Pacific Partnership Agreement Amendment Bill - In Committee', New Zealand Parliament, 8 November 2016.

253 Ibid.
} 
Curran lamented: 'We are poorer as a nation for that, and my concern is that when this deal was negotiated, there were people who did the negotiating who did not seem to get that.' In particular, she commented that such a regime would have a harsh impact upon educational and cultural institutions in New Zealand. ${ }^{254}$

\section{Japan and Singapore}

In July 2018, Japan's Upper House approved the TPP-11 Bill, while extending copyright duration. ${ }^{255}$ Japan retained the proposal to extend copyright protection from life plus 50 years to life plus 70 years. This is at odds with the suspension in effect with TPP-11.

There was some disquiet about this decision. Opposition lawmaker Taro Yamamoto asked whether the ruling coalition had calculated the economic benefits and costs to Japan of a 20 -year copyright extension. ${ }^{256}$ The government said it couldn't answer his question 'quantitatively'. ${ }^{257}$ It seems incredible that Japan did not engage in evidence-based policy making in respect of the decision to enact a copyright term extension. Chiki Ogiue observed that, as a published writer, he did not see any real benefit in the extension for the vast majority of Japanese creators. ${ }^{258} \mathrm{He}$ noted: 'I have no intention of leaving my copyrights to my descendants. ${ }^{259}$ In his view, 'It's fine with me if my books eventually become free to anyone 50 years after I write it. ${ }^{260}$

Singapore had previously agreed to a copyright term extension as part of a trade agreement with the United States. ${ }^{261}$

\section{Mexico and other Developing Nations}

Mexico has a copyright term of 100 years after the death of the author. Mexico, of course, pushed for even longer copyright terms in the debate in the TPP. Comparative copyright scholar Blayne Haggart has provided a useful account of the position in Mexico. ${ }^{262} \mathrm{He}$ emphasised that the super-extended copyright term in Mexico was the product of lobbying by copyright industries. Nonetheless, Haggart makes the point that the law on the books does not necessarily translate to the law in action. He comments that Mexico does not necessarily have strong formal or informal compliance with the copyright regime.

Chile agreed to a copyright term extension in 2003, to life plus 70 years. Peru has adopted a copyright term extension of life plus 70 years. Malaysia still has a baseline copyright term

\footnotetext{
254 Ibid.

255 Taro Yaguchi, 'Japan's Upper House Approves TPP-11 Bill for Freer Trade while Extending Copyright Duration', Keisen Associates, 13 July 2018.

${ }_{256}$ Philip Brasor, 'Rationale for Extending Japan's Copyright Protections Unclear', Japan Times, 22 December 2018.

257 Ibid.

258 Ibid.

259 Ibid.

260 Ibid.

261 Singapore-United States Free Trade Agreement, signed 6 May 2003 (entered into force 1 January 2003).

262 Blayne Haggart, Copyfight: The Global Politics of Digital Copyright Reform, Toronto: University of Toronto Press, 2014.
} 
of life plus 50 years. Vietnam follows the Berne Convention standard. Brunei has a copyright term of life plus 50 years.

The Washington Principles on Copyright Balance in Trade Agreements 2017 called for countries to resist copyright term extensions. ${ }^{263}$ The document notes: 'Copyright duration remains a debated issue at both the national and international level. ${ }^{264}$ The statement confirms: 'There is no evidence to suggest that the private benefits of copyright term extensions ever outweigh the costs to the public.' ${ }^{265}$ The declaration acknowledges: 'There are serious proposals being considered around the world to limit the extension of term beyond the multilateral minimum to cases where active owners assert their rights. ${ }^{266}$ The document concludes: 'We call on the parties to adhere to the standards for copyright term reflected in the World Intellectual Property Organization copyright treaties.' 267

\section{CONCLUSION}

The TPP provided for an extensive catalogue of obligations and prescriptions in respect of copyright law in the Pacific Rim. The international treaty is a TRIPS++ Agreement - which has more extensive obligations than the TRIPS Agreement 1994 or TRIPS+ Agreements like the Australia-United States Free Trade Agreement 2004. The agreement is quite revolutionary in terms of its approach to the aims, objectives and purposes of copyright law. As a result of heavy lobbying by Hollywood, the recording industry and publishers, the TPP sought to extend the term of copyright across the Pacific Rim. However, the TPP-11 suspended the clause on the copyright term extension. There has been concern that the provision will be revived in the future - particularly now that Canada has surrendered to the United States on the topic as part of the USMCA.

There has been larger concern that the TPP will result in greater fragmentation of international regulation and governance of copyright law and electronic commerce. The regional agreement will dilute the key role of international organisations such as the World Intellectual Property Organization and the World Trade Organization. There will also be complications over the relationship between multilateral and bilateral copyright obligations and the proposed new regional agreement.

To the disappointment of the copyright industries, and the consternation of the big information technology companies, United States President Donald Trump issued an executive order in 2017 withdrawing the United States from the negotiations and the agreement. ${ }^{268}$ This threw into doubt the future of the TPP. At the time, a number of the remaining participants - including Australia and New Zealand - mooted the possibility of an agreement without the participation of the United States. ${ }^{269}$ Australian Prime Minister Malcolm Turnbull discussed

\footnotetext{
263 Washington Principles on Copyright Balance in Trade Agreements 2017.

264 Ibid.

265 Ibid.

266 Ibid.

267 Ibid.

268 The White House, 'Presidential Memorandum Regarding Withdrawal of the United States from the Trans-Pacific Partnership Negotiations and Agreement', Press Release, 23 January 2017.

269 Radio New Zealand, 'NZ and Australia to Work Together to Salvage TPP - English', Radio New Zealand, 17 February 2017.
} 
the potential for countries to join the TPP to compensate for the departure of the United States. ${ }^{270}$ New Zealand Prime Minister Bill English argued that 'it would be quite beneficial for Australia and New Zealand to show some confidence that this could be moved forward'. ${ }^{271}$ In the end, the TPP-11 accord was reached, with suspensions of some key measures (including in respect of the copyright term).

Nonetheless, the template of the TPP remains a powerful model. The United States administration under Trump offered $T P P$-style text on intellectual property in the NAFTA renegotiations with Canada and Mexico. ${ }^{272}$ There has also been discussion about the impact of the USMCA on the copyright term. ${ }^{273}$ Australia and Japan have promoted TPP-style text in the negotiations over the Regional Comprehensive Economic Partnership. ${ }^{274}$

'Rock against the TPP' organisers Evan Greer, Tom Morello and Evangeline Lilly maintained that Trump should not receive credit for the demise of the TPP. ${ }^{275}$ They contended that the downfall of the TPP was due to concerted organisation and pressure from civil society. The organisers stressed that 'Internet freedom activists mobilized thousands of websites for online protests that bombarded lawmakers with emails and phone calls ${ }^{276}$ and commented: 'Hard-hitting activism and public outcry slowed the TPP down, and as a result, dragged it fully into the spotlight just as the US headed into a contentious election season. ${ }^{277}$ They reflected: 'Now more than ever, it's crucial that Americans understand how the TPP was really defeated. ${ }^{278}$ The activists concluded that 'an organized and educated public can take on concentrated wealth and power and win'. ${ }^{279}$ However, the United States' withdrawal from the TPP did not in the end result in the death of the TPP more generally. The revival of the TPP-11 showed that there was a need for a wider, more global fair trade movement.

270 'PM Malcolm Turnbull says China Could Join the TPP after the US and Donald Trump Opted Out', News.com.au, 25 January 2017.

${ }^{271}$ Radio New Zealand, 'NZ and Australia to Work Together to Salvage TPP - English', Radio New Zealand, 17 February 2017.

272 Jeremy Malcolm, 'NAFTA Renegotiation will Resurrect Failed TPP Proposals', Electronic Frontier Foundation, 31 March 2017.

273 Eriq Gardner, 'Donald Trump's New Trade Deal with Mexico Leads to Confusion about Copyright Term', Hollywood Reporter, 27 August 2018.

274 Regional Comprehensive Economic Partnership.

275 Evan Greer, Tom Morello and Evangeline Lilly, ‘The TPP Wasn't Killed by Donald Trump - Our Protests Worked', The Guardian, 28 November 2016.

276 Ibid.

277 Ibid.

278 Ibid.

279 Ibid. 